\title{
Technology Adoption and Adaptation in Canada's West Coast Shipyards 1918-1950
}

\section{Chris Madsen}

La construction navale a émergé comme une industrie importante dans la province de la Colombie-Britannique au cours de la première moitié du XXème siècle. Les demandes des guerres mondiales, des marchés commerciaux autant étrangers que côtières avec le développement des ports qui y est associé, des relances gouvernementales de l'industrie et des fabriques, ainsi qu'une économie régionale basée sur les commodités, ont influencé les décisions derrière la construction de navires. Les entreprises privées et les responsables des achats du gouvernement ont comparé les progrès réalisés dans la construction navale avec les développements dans d'autres pays maritimes de premier plan, plus particulièrement le Royaume-Uni et les États-Unis. La construction navale en Colombie-Britannique reflète un amalgame de tradition artisanale britannique, la pratique de production nordaméricaine, et la psychologie de propriétaires individuels et leur personnel. En conséquence, l'adoption de nouvelles technologies dans cette industrie " moderne " s'est basée sur la perception d'adaptabilité et l'acceptation. Les questions significatives concernaient le choix entre la construction en bois ou en acier, les investissements d'infrastructure à long terme en vertu de la législation sur les subventions pour les cales sèches, la persistance de rivetage par rapport à la soudure pour l'assemblage des coques, la fourniture locale des moteurs de marine et de la machinerie complexe, et la finition appliquée à la construction neuve et aux conversions. Les chantiers navals de taille moyenne de la cote ouest du Canada éprouvaient toujours du mal à se tenir au courant des dernières technologies afin de maintenir une compétitivité et à compenser d'autres limitations qui pèsent sur la construction générale navale en tant qu'une industrie lourde viable.

The Canadian federal government's announcement in January 2012 awarding major shipbuilding contracts to bidding contenders on the country's east and west coasts has once again awakened national interest in a fragile heavy industry and its historical record. ${ }^{1}$ This commitment over the next three decades comes with promises of skilled

1 Prime Minister of Canada Stephen Harper, "The National Shipbuilding Procurement

The Northern Mariner/le marin du nord, XXII No. 3, (July 2012), 235-282 
jobs, business activity, and stimulation of economic development in surrounding communities. Some people in British Columbia, so often nursing a sense of alienation from the sway in national politics of more heavily populated regions in Central Canada and accustomed to being overlooked in past government decision-making, almost equated the outcome with winning the lottery. Admittedly, the lucky "Canadian" company, Seaspan Marine Corporation, which operates repair and assembly facilities in North Vancouver and Esquimalt, was a deserving private enterprise that, through hard work behind a detailed 30,000 page submission answering requirements in the government's demanding request for proposal, delivered a convincing case based on its own merits. ${ }^{2}$ Notwithstanding British Columbia premier Christy Clark's lavish praise for the team effort, the province not long before withdrew funding for a proposed national shipbuilding museum adjacent to Seaspan's Vancouver Shipyards citing the expense of hosting the 2010 Winter Olympics and remained vague about support in the form of subsidies and apprenticeship programs following the federal announcement. The history of shipbuilding on Canada's west coast, though hardly forgotten, frequently gets distorted and misinterpreted in the current policy debate over the value of shipbuilding to regional development and employment in Canada. ${ }^{3}$ While the honeymoon period still lasts, governments and private enterprise at least appear enthusiastic about forging a renewed partnership to build domestically ships necessary for the national interest.

Shipbuilding in Canada, especially on the west coast, has long relied upon government encouragement and public monies. A definite boom and bust cycle characterized the industry's growth from the start of the twentieth century up to the present day. Previously, the high times for Canadian shipbuilding were the years at the end of the First World War, the extraordinary demands for merchant shipping and escort warships in the Second World War, and batch buying during the extended Cold War supplemented by ferry orders from public transportation bodies. Companies engaged in shipbuilding, both established and newcomers, received enough business from government contracts to make profits and sustain operations to a greater or lesser extent. For the most part, the literature tends to focus on those intense periods of heightened shipbuilding effort in relation to military requirements. ${ }^{4}$ In fact, Canada's wartime shipbuilding can only be understood fully in the context of North America supply meeting war needs globally of which it was a part and the usual comparison to the United

Strategy" (12 January 2012) http://www.pm.gc.ca/eng/media.asp?category=5\&pageId=48 \&id $=4577$

2 Seaspan Marine Corporation is associated with the Washington Companies, owned and controlled by Montana businessman Dennis Washington. http://www.seaspan.com; http://www.washcorp.com/

3 Brian Morton, "Seaspan contract latest chapter in rich shipbuilding history," Vancouver Sun (22 October 2011), C3.

4 James Pritchard, A Bridge of Ships: Canadian Shipbuilding during the Second World War (Montreal and Kingston, 2011). Bruce Hendrickson, "Priming the Flower's Stem: US Maritime Industries Prepare for War," International Journal of Maritime History 18 (June 2006), 129-152. Michael Lindberg and Daniel Todd, Anglo-American Shipbuilding in World War II: A Geographical Perspective (Westport, 2004). 
States and United Kingdom. The level of business and employment in British Columbia shipyards during those boom times was truly exceptional. More typical, shipbuilders struggled when government contracts were less forthcoming and available commercial work proved barely sufficient. Companies turned to ship repair, branched out to related manufacturing lines in the broader economy, underwent consolidation through strategic plays and buy-outs, or merely closed after bankruptcy and financial insolvency. Those down times were tough on shipbuilders determined to stay in the business field, whether out of stubborn faith in craft, family connections, or eternal hope of better days. Remaining companies and industry lobbyists tried to attract government attention by calls for subsidies and better sequenced production runs allowing constant work. Most longstanding shipyards lived through both worlds of boom and bust. Margins of success in shipbuilding on Canada's west coast ultimately depended upon leadership to make sound business decisions within the prevailing political and economic environment, the ability to innovate through better production and lower costs, and marshaling adequate human and fiscal resources. Adoption and adaptation of technology was central to attaining this fine balance during the years between 1918 and 1950.

Whatever marvelous achievements Canada's west coast shipyards achieved in scale and quantity during the war years, shipbuilding forever followed an equivocal business model trapped in the paradox of traditional practice embracing modernity. The setting was the young British Columbia industrial scene as the province opened up to the rest of the world and contributed to national pursuits such as trade and participation in external conflicts not of its own making. Shipbuilding embodied a certain coming of age in business and industry, as large-scale manufacturing set the standard. Envisioned creation of shipbuilding clusters rivalling the maritime leader of the time, the United Kingdom (and the bigger United States) leveraged the advantages of a moderate climate allowing year round construction and easy access to the Pacific and oceans beyond. Those businessmen and workers with the associated skills and technical expertise gravitated to British Columbia as a place of possibilities in the shipbuilding field. The resulting companies concerned with shipbuilding established a capacity in search of a market, one which it was hoped would add to the prosperity of themselves and the province. The industry imported technologies, thoroughly leading edge at the time, to improve production processes for greater ease and efficiency in construction of ships and the profits that derived from them. While outwardly modern, shipbuilding still remained essentially a very dirty occupation reliant upon quality of workmanship and design, more craft than mass industrial in nature. Shipbuilders on Canada's west coast may have chased big dreams, but they ran up against higher relative labor and transportation costs, variable markets and sources of supply, and tepid government interest in nurturing an industry requiring major investment and visionary policy beyond the short term. Despite such handicaps, British Columbia shipyards built ships and built them well with the latest technology available.

\section{Wood versus Steel Construction}

British Columbia, Canada's westernmost province located between Washington State and Alaska, was founded on the economic sectors of forestry, mining, and fishing. 
The rugged wilderness of the Pacific north-west where coastal mountains rose out of the sea canvassed by lush green rain forests provided many opportunities for stimulus and economic exploitation. ${ }^{5}$ The capital city in the former British colony moved from New Westminster on the mainland to Victoria at the southern tip of Vancouver Island, though metropolitan Vancouver, with its natural harbor and access to major rail and river transportation routes, emerged as the largest and most important port city in the province. Prince Rupert, another natural deep water port farther north up the coast, was terminus of the Grand Trunk Pacific Railway, completed in 1914 just prior to the First World War. ${ }^{6}$ The closest American competitors for Pacific trade and shipping were Seattle in Puget Sound, Portland, Oregon, and San Francisco and Los Angeles, California; each of those cities, like Vancouver, was important to regional economies and developed into major ports for getting resource commodities to international markets. Though San Diego became the main base and Hawaii eventually the advance base for the U.S. Navy, navy yards and docking facilities elsewhere along the U.S. coast also met fleet requirements for maintenance and building. The principal Canadian naval base and dockyard was located at Esquimalt near Victoria, transferred from British to Canadian control in 1910 with establishment of the Royal Canadian Navy. ${ }^{7}$ Canada entered the First World War with an old, worn-out ex-Royal Navy training cruiser on station that fortunately never met up with the Imperial German East Asia squadron which sank mercantile shipping and two British armored cruisers before being hunted down and destroyed itself off the Falkland Islands. ${ }^{8}$ Any naval threat to the Pacific north-west was effectively removed, long before the United States entered the world war on the Allied side in 1917. Previously, shipyards on Canada's west coast had built mostly wooden schooners, fish boats, river boats, and passenger ferries, given the abundance of lumber from local trees, capacity in smaller facilities, and immediate domestic requirements. ${ }^{9}$ British Columbia,

5 Jean Barman, The West Beyond the West: A History of British Columbia (Toronto, 2007), 9. Forrest Duncan Pass, "Pacific Dominion: British Columbia and the making of Canadian nationalism, 1858-1958," PhD dissertation, University of Western Ontario, 2008.

6 W.B.M. Hick, Hay's Orphan: The Story of the Port of Prince Rupert (Prince Rupert, 2003), 31. Frank Leonard, A Thousand Blunders: The Grand Trunk Pacific Railway Company and Northern British Columbia (Vancouver, 1996), 260-262.

7 F.V. Longstaff, Esquimalt Naval Base: A History of Its Works and Its Defences (Victoria, 1942), 68.

8 Gilbert Tucker, The Naval Service of Canada vol. 1 (Ottawa, 1952), 266-277. Barry M. Gough, "Canada and the North Pacific, 1871-1914: Problems of a Lion's Cub in an Open Den," South Atlantic Quarterly 76(Spring 1977), 363. Roger Sarty, "Canadian Maritime Defence 1892-1914," Canadian Historical Review 71(December 1990), 488.

9 Rick James, "Staying Afloat: Saving B.C.'s Lumber Industry by Shipbuilding," British Columbia Historical News (renamed British Columbia History) 29(Fall 1996), 20. David Farrell, "Keeping the Local Economy Afloat: Canadian Pacific Navigation and Ship-owning in Victoria, 1883-1901," The Northern Mariner/Le marin du nord 6(January 1996), 40. Eric W. Sager, "The Shipping Industry in British Columbia from 1867 to 1914," The Northern Mariner/Le marin du nord 3(July 1993), 65. Jerry E. Green, "Riverboat Technology and Riverboat Builders for the Yukon River, 1896-1906," Alaska History 19(2004), 47. Art Downs, Paddlewheels on the Frontier: The story of British Columbia and Yukon sternwheel 
like neighboring Washington State, soon met new demands in shipbuilding for coastal defense and vessels able to carry war materials to distant countries and theaters of operations during the war emergency.

The number of companies operating shipyards of sufficient size and experience to undertake that war work was a limiting factor. Yarrows Limited, a subsidiary of a Scottish destroyer and small warship builder on the Clyde River, was probably best placed. ${ }^{10}$ Adjacent to the Esquimalt naval base, the shipyard had been established in anticipation of pre-war Royal Canadian Navy orders that never materialized on lands purchased from an established marine railway firm. Notwithstanding, the Canadian government declined to issue orders for warships larger than trawlers and drifters and then only to yards in eastern Canada where costs were demonstrably lower. ${ }^{11}$ The shipyard's youthful director, Norman Yarrow, secured business instead in conversions and ship repair, construction of steam-driven river boats destined for British colonial service, and fabrication of components for other shipbuilders in Canada and the United States. After the war, Yarrows under Norman's stewardship built several Canadian Pacific passenger ships for coastal routes. ${ }^{12}$ The navy appeared unwilling to take a risk on an unproven shipyard, whatever its supposed pedigree in naval construction abroad. Warships stationed at Esquimalt were predominantly foreign sourced, including two small submarines purchased clandestinely with provincial funds by British Columbia premier Richard McBride from Seattle and given over to naval service. The American intermediary in that deal, businessman James Paterson, later approached the British Pacific Engineering and Construction Company, to assemble submarines of Electric Boat Company design for the Russian and British governments at a yard on Vancouver's Burrard Inlet, a blatant attempt to thwart U.S. neutrality laws. ${ }^{13}$ Though small, these

steamers (Sidney, 1972).

10 Alastair Borthwick, Yarrow and Company Limited: 1865-1977 (Glasgow, 1977), 42. Hugh Peebles, Warshipbuilding on the Clyde (Edinburgh, 1987), 69. Fred M. Walker, Ships \& Shipbuilders: Pioneers of Design and Construction (Barnsley, 2010), 162-164. Thomas C. Sorby, List of docks, wharves, shipyards, marine railways and other facilities for repairing ships in the port of Victoria, British Columbia (Victoria, 1919).

11 Michael L. Hadley and Roger Sarty, Tin-Pots and Pirate Ships: Canadian Naval Forces and German Sea Raiders 1880-1918 (Kingston and Montreal, 1991), 208. William Johnston, "The Royal Canadian Navy and the First World War," in Richard H. Gimblett (ed.), The Naval Service of Canada 1910-2010: The Centennial Story (Toronto, 2009), 33.

12 British Columbia Archives, Victoria (hereafter BCA), ms-1241, J.S. Marshall, corporate history of Yarrows Limited, 1963. Norman Yarrow lived in Esquimalt nearer the shipyard before buying a luxury view house located in Victoria's upscale Edgecliffe neighborhood, his older brother Harold (who like his father was eventually knighted for work connected to naval construction) ran the main family shipbuilding firm in Scotstoun, Scotland, and another brother, Eric, died in military action at Ypres on the Western Front during 1915. Eleanor C. Barnes (Lady Yarrow), Alfred Yarrow: His Life and Work (London, 1923), 241-244. A short biography of Norman Yarrow is attached to a scholarship in his name at the University of Victoria: http://web.uvic.ca/givingtouvic/Donor_Bio/Y/Yarrow_Norman.php

13 W. Kaye Lamb, "Building Submarines for Russia in Burrard Inlet," BC Studies 71 (Autumn 1986), 9. Gaddis Smith, Britain's Clandestine Submarines, 1914-1915 (New Haven and 
submersibles were the most technically sophisticated naval craft constructed in British Columbia until that time and for some years to come. Other Vancouver-area shipyards clamored to be given the opportunity to build smaller warships and freighters with expanded facilities, modernized equipment, and additional technical know-how. Excess shop floor space and machinery in some firms had been devoted to production of shell casings for contracts on behalf of the British Imperial Munitions Board. ${ }^{14}$ The chief problem was shortage of steel due to war demands and lack of blast furnace and rolling mill capacity in the Pacific north-west. The basic materials for ships and other munitions, therefore, had to be shipped from other parts of North America, thereby increasing cost and pressure on overstretched transportation networks. The only suitable alternate building material in adequate supply was wood.

Any decision to build war-purpose ships in British Columbia, out of either wood or steel, held far-reaching ramifications for the shipbuilding industry to be developed and possible commercial usage later on. Although ships had been constructed from wood for centuries and indeed decades in the province, steel was unquestionably the preferred medium. ${ }^{15}$ Steel was stronger, weighed less in relative terms, and allowed for ships of larger tonnage size and in turn carrying capacity. All advanced naval warships, passenger liners, and most modern merchant vessels were built of steel. Though comparable in some respects, the skills and production processes for working in wood and steel were sufficiently different that shipyards specialized in either one or the other. Accordingly, the provincial government appointed a commission which canvassed shipbuilders, shippers, and interested parties about the pros and cons behind wood and steel ship construction. ${ }^{16}$ The detailed replies received back reflected little consensus: many companies favored building wood ships for the existing lumber export trade and emerging markets, a smaller number viewed steel construction as the logical next step, and a few even questioned why the government should become involved in speculative ventures with public money. Shortly thereafter, the provincial legislature passed the British Columbia Shipping Act which afforded some limited subsidies and loans for shipyards devoted to the building of ships for carriage of freight from the province on

London, 1964). Bill Lightfoot, Beneath the Surface: Submarines built in Seattle and Vancouver, 1909-1918 (Vancouver, 2005).

14 Canadian Pacific Railway Archives, Montreal, RG 3 General Executive Assistant general correspondence box 19 file 3 documents 1010, letter F.L. Wanklyn to H.C. Grout, 23 July 1915. David Carnegie, The History of Munitions Supply in Canada, 1914-18 (London, 1925). Keith Neilson, "R.H. Brand, the Empire and Munitions from Canada," English Historical Review 126 (December 2011), 1438-1439.

15 William H. Thiesen, Industrializing American Shipbuilding: The Transformation of Ship Design and Construction 1820-1920 (Gainesville, 2006), 170. William H. Thiesen, "Origins of Iron Shipbuilding," International Journal of Maritime History 12 (June 2000), 91. C.K. Harley, "On the Persistence of Old Techniques: The Case of North American Wooden Shipbuilding," Journal of Economic History 33 (June 1973), 372-399.

16 BCA, British Columbia Executive Council Shipbuilding Committee, GR 1508 box 2 file1, circular letter, 12 January 1916. 
ocean routes, specifying neither wood nor steel. ${ }^{17}$ In the nature of a compromise, the encouragement actually influenced established shipyards and new companies entering the shipbuilding field to grow and seek out orders from government bodies and other customers. The Imperial Munitions Board, purchasing on British behalf, distributed contracts for 2,800 ton deadweight wood steamers amongst shipyards in Victoria and Vancouver's Lower Mainland. ${ }^{18}$ These ships were an expedient, a throwback before steel construction never meant to last beyond immediate war duties. Such wood ships, however, utilized locally sourced materials and stayed within the capabilities of existing British Columbia shipyards, as yet unfamiliar with more complicated steel construction. The first ships built of steel in the province were not completed until 1918.

The technology behind ships made of steel necessarily entailed shipyards becoming larger and more efficient in operating. Steel plates were ordered and delivered from far away, component parts cut and formed, and then assembly happened on building ways in a progressive fashion with gangs of workers. The work involved a considerable degree of orchestration and care in following detailed design plans, either externally obtained or done in-house. In North Vancouver, Wallace Shipyards Company, which transitioned from wood to steel construction, early realized the profound change in the business environment overtaking shipbuilding in British Columbia. ${ }^{19} \mathrm{New}$ equipment acquisitions meant steel ships could be built from the hull up, including provision of propelling and auxiliary machinery. By this means, the shipyard fulfilled contracts from the Imperial Munitions Board on time and received follow on orders from foreign buyers and the Canadian government for more steel merchant ships. ${ }^{20}$ The mode of production, however, was still predominantly craft-like given the proclivities of Alfred Wallace, the English-trained proprietor and his managers. Over on Vancouver's False Creek, a different approach was tried by bridge builder and steel fabrication firm J. Coughlan \& Sons which had acquired enough real estate to build larger numbers of steel merchant ships. The scale of operation, soon the biggest in the province, drew more than a little inspiration from similar producers for the Emergency Fleet Corporation in the United States. $^{21}$ The first Coughlan-built 8,800 ton steel ships were actually an American

17 British Columbia Shipping Act, S.B.C. 1916, c. 57: see Appendix A for full text. G.W. Taylor, Shipyards in British Columbia: The Principal Companies (Victoria, 1986), 86-87.

18 The Marine Retirees Association Marine Workers and Boilermakers Industrial Union Local No. 1, A History of Shipbuilding in British Columbia (Vancouver, 1977), 10. Fred Hopkins, "Emergency Fleet Corporation Ship Construction in World War I in the Pacific Northwest," The Northern Mariner/Le marin du nord 4 (October 1994), 16. William Joe Webb, "The United States Wooden Steamship Program during World War I," American Neptune 35(October 1975), 277-280. Louis A. Hough, A Fleet to Be Forgotten: The Wooden Freighters of World War One (San Francisco, 2009).

19 Francis Mansbridge, Launching History: The Saga of Burrard Dry Dock (Madeira Park, 2002), 14-21.

20 David R. Conn, “The War Orders," Canadian West 8(Summer 1987), 86. University of British Columbia Library Special Collections (hereafter UBC/SS), Daryl L. Logan, "The Influence of World War I on Shipbuilding in Vancouver," 1953.

21 S.C. Heal, Conceived in War, Born in Peace: Canada's Deep Sea Merchant Marine 
standardized design, laid down using American technical experts and Canadian workers. Ship hulls were assembled as quickly as possible; common engines and other necessary machinery arrived from other distant plants and then installed as required according to definite progress schedules. The fastest completed ship hull, christened War Noble, was launched in a record 63 days of working time. Arguably still very small operations comparatively speaking to those in nearby Seattle and other American cities engaged in wartime shipbuilding, Vancouver's shipyards approached serial production with the limited number of ships on order for government war authorities. ${ }^{22}$ The armistice ending the First World War removed the rationale for emergency shipping, though the wave of steel shipbuilding in British Columbia continued unabated.

Government intervention artificially kept Canada's west coast shipyards more or less near capacity into the immediate postwar period. The prospect of closing down the large wartime industry overnight was daunting. Thousands of industrial workers at Coughlan's shipyard went out on strike protesting wages and signs of slackening business, an action that resulted in appointment of a government royal commission to examine the demands being made. ${ }^{23}$ Company owners and authorities feared the spread of industrial radicalism to other shipyards and related manufacturing industries provincewide, thereby upsetting the delicate social balance. In the meantime, shipping companies and exporters looked forward to rebound of external demand for the province's resource commodities after war year declines. Vancouver area shipyards received a number of orders for ships from home and foreign sources replacing older ones or adding to working fleets. Smaller coastal ships were often wood in construction, whereas trans-ocean ships were steel. A glut of war emergency hulls, though typically worn-out or ill-suited in design for specific commercial duties, generally kept prices depressed, and shipbuilders occasionally underbid simply to keep the business. In this context, Canada's federal government decided to establish a publically-owned merchant fleet, named the Canadian Government Merchant Marine, and gave preference to domestic shipbuilders for the

(Vancouver, 1992), 37. William C. Mattox, Building the Emergency Fleet: A Historical Narrative of the Problems and Achievements of the United States Shipping Board Emergency Fleet Corporation (Cleveland, 1920). Gail Radford, "William Gibbs McAdoo, the Emergency Fleet Corporation, and the Origins of the Public-Authority Model of Government Action,” Journal of Policy History 11(January 1999), 59-88.

22 William J. Williams, “Accommodating American Shipyard Workers, 1917-1918: The Pacific Coast and the Federal Government's First Public Housing and Transit Programs," Pacific Northwest Quarterly 84(April 1993), 52. Glenn A. Stackhouse, "The Anglo-American Atlantic convoy system in World War I, 1917-18," Ph.D. dissertation, University of South Carolina, 1993, 462. See also generally, William J. Williams, The Wilson Administration and the Shipbuilding Crisis of 1917: Steel Ships and Wooden Steamers (Lewiston, 1992).

23 Dennis Murphy (chairman), The Coughlan Shipyard Dispute: Final Report of the Royal Commission Appointed to Enquire into the Differences, 24 July 1919. James R. Conley, "Frontier Labourers: Crafts in Crisis and the Western Labour Revolt: The Case of Vancouver, 1900-1919," Labour/Le travail 23(Spring 1989), 24. UBC/SS, spam6002, Elizabeth Lees, "British Columbia Shipyard Workers' Organization 1916-1919: A Case Study of War Work and Industrial Unionism," 1987. Robert L. Friedheim, "Prologue to a General Strike: The Seattle Shipyard Strike of 1919," Labor History 6 (Spring 1965), 138-139. 
construction of steel cargo-carrying vessels. ${ }^{24}$ The strategy served a fourfold purpose: employment eased back to normal levels by staggered work; business and industrial leaders cheered the economic development and potential; greater participation in shipping routes and international trade serving Canada challenged the stranglehold of foreign companies; and, similar developments fostering and protecting a fledgling U.S.-flagged merchant marine apparently pointed the way.

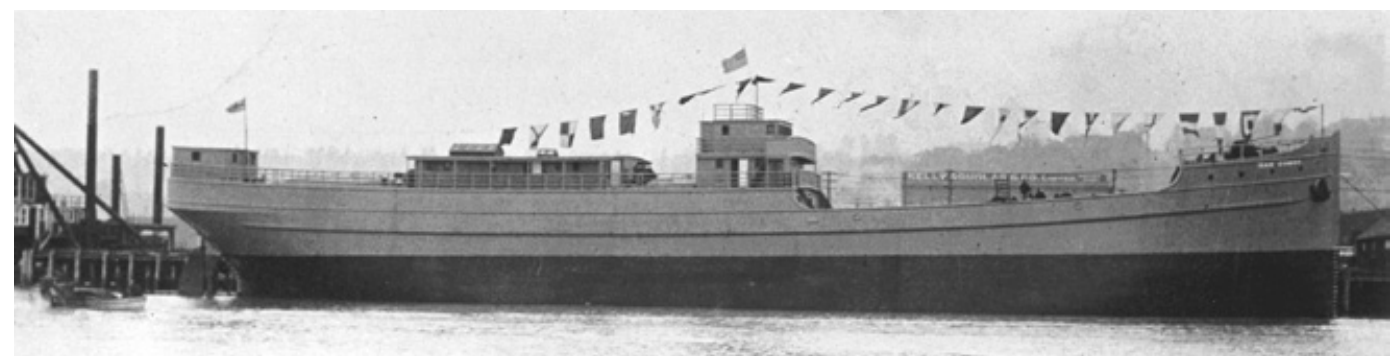

Illustration 1: Clean hull lines of War Comox, typical example of the standardized war-emergency wood cargo vessels built in British Columbia to an American design, shortly after launch from a shipyard on Poplar Island in April 1918. Note the American flag flying over the superstructure. (New Westminster Public Library)

The beneficiaries of this bold policy were larger operating shipyards in British Columbia. The best of the wartime entrants, like Wallace and Coughlan, received orders for building steel cargo ships with steam propulsion to an adapted wartime design. Due to local entreaties to spread the business around, additional government contracts went to other companies not primarily involved in the wartime shipbuilding effort. Victoria Machinery Depot and Prince Rupert Dry Dock, though both previously engaged in ship repair and fabrication of ship components, built steel hulls at existing and new facilities established for the purpose. While supply of workers with necessary skills in those locales proved vexing and general costs were higher, timely completion of ships was much less an issue than before because the Canadian Government Merchant Marine found trouble profitably employing the ships already on hand. An economic downturn and tightening markets against stiff foreign competition undermined the whole business model. Canada's government-owned merchant marine, like its American counterpart, suffered mounting losses year after year and shrank by selling off ships at a fraction of original building cost. ${ }^{25}$ To add insult to injury, the buyers were frequently the same foreign competitors dominating international shipping routes. During the short post-war boom, shipyards in British Columbia delivered newer steel cargo ships built to modern standards into a fleeting market with considerable government encouragement.

24 Kenneth S. Mackenzie, "C.C. Ballantyne and the Canadian Government Merchant Marine, 1917-1921," The Northern Mariner/ Le marin du nord 2(January 1992), 3.

25 Andrew Gibson and Arthur Donovan, The Abandoned Ocean: A History of United States Maritime Policy (Columbia, 2000), 122. American Bureau of Shipping, The American Merchant Marine (New York, 1933). 


\section{Scramble for Floating Dry Docks and Graving Docks}

To the companies and business leaders themselves, the outlook for shipbuilding on Canada's west coast turned discouraging with cessation of merchant marine contracts. Of more than three dozen large and small shipyards running in early 1918, fewer than ten remained three years later. ${ }^{26}$ Temporary wartime shipbuilders affiliated with lumber companies such as Cameron Genoa Mills in Victoria, W. Lyall Shipbuilding Company in North Vancouver, and New Westminster Shipbuilding and Engineering Company first closed down with declining interest in larger wood ships. That form of construction carried on in smaller boat building yards catering to the fishing and forestry sectors. Selected shipyards in Prince Rupert, Victoria, and Vancouver finished the last Canadian Government Merchant Marine steel cargo ships, but received no further follow-on orders because the government needed no more ships. When fire suddenly gutted the buildings and ways at Coughlan's False Creek site, the company's directors voted against rebuilding the shipyard due to dim prospects and wound down the business division in favor of other strategic directions after a somewhat disappointing foray into shipping. The closure left Wallace as the shipyard best equipped to take on steel ship orders in the greater Vancouver area, if not the province since rival contenders Yarrows and Prince Rupert Dry Dock were predominantly working ship repair. Canadian Pacific Railway, which customarily acquired its passenger ships for British Columbia coastal service from shipbuilders in the United Kingdom, took a chance on the North Vancouver shipyard to build the replacement Princess Louis, delivered on time and marginally over budget. ${ }^{27}$ This crowning achievement, however, represented little more than a one off since Canadian shippers reverted back to buying cheaper abroad. No steel ship of any significant size or sophistication was built at Wallace or elsewhere on Canada's west coast for the next two decades. In the United States, private shipyards starving for new orders along Pacific coast faced the very same situation. ${ }^{28}$ Companies determined to stay in shipbuilding lobbied whenever possible for business and relied on proximity to ports or naval bases to leverage any opportunities that came along. In the absence of regular work, basic payroll and plant maintenance commitments were often hard to meet, never mind financing for capital enhancements to stay competitive and paying profits to shareholders and owners. Government assistance for the industry coalesced around

26 Aitken Tweedale (ed.), Shipbuilding and Shipbuilders of British Columbia with allied industries (Vancouver, 1918).

27 Mansbridge, 41. Robert D. Turner, The Pacific Princesses: An illustrated history of Canadian Pacific Railway's Princess fleet on the northwest coast (Victoria, 1977).

28 John G. B. Hutchins, "History and Development of Shipbuilding 1776-1944," in F.G. Fassett (ed.), The Shipbuilding Business in the United States of America vol. 1 (New York, 1948), 56. James R. Moore, The Story of Moore Dry Dock Company (Sausalito, 1994), 14-16. Bancroft Library, University of California, Berkeley (hereafter BL/UC Berkeley), Bethlehem Steel Company Shipbuilding Division: A Century of Progress 1849-1949 (San Francisco, 1949). Martin Stopford, Maritime Economics (New York, 2009), 626-627. Deborah A. Hirshfield, "From Hog Islanders to Liberty Ships: The American Government and Merchant Ship Construction in Two World Wars," American Neptune 54 (Spring 1994), 91. 
subsidies and repayable loans for the construction of dry docks.

The dry dock was a technology that the most agile shipyards on Canada's west coast strove to attain or at least have privileged access to. It allowed ships to be built, serviced, and repaired out of the water. A graving dock was excavated on land, lined with stone or cement, and a closeable gate at one end enabled water to be pumped out or flooded. A floating dry dock, on the other hand, was a mechanical apparatus, typically made out of steel or wood, sufficient to lift a cradled ship out of the water with ballast tanks and pumps. The graving dock was a very expensive proposition, required well-located shoreline real estate, and typically took some time to build. The floating dry dock followed ship construction methods and held the advantage of mobility by tow or selfpropulsion. Graving docks and floating dry docks ranged in size depending upon the ships to be accommodated. The existing floating dry dock at Prince Rupert was central to the local shipyard and repair facilities, even after control passed from the insolvent Grand Pacific Trunk Railway to the state-run Canadian National Railways. Despite numerous false starts at getting a large graving dock

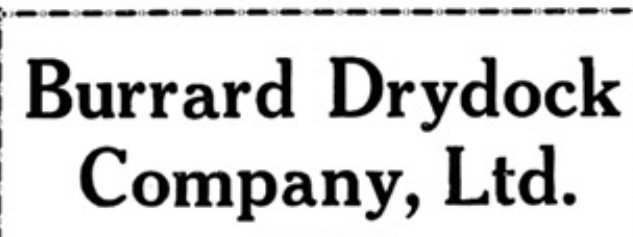

Successors to

Wallace Shipbuilding \& Drydock Co. Ltd.

THE MOST MODERN SHIP REPAIR PLANT ON THE PACIFIC COAST

20,000-ton Floating Drydock

Engineers - Shipbuilders - Founders

GRAIN LINING A SPECIALTY

Telephones: North 102-3-4

City Office: 355 Burrard

Telephones: Seymour 7940-6045

Cable Address: Drydock, Vancouver

Iain Office and Works: North Vancouver, B.C.

Illustration 2: Possession of a dry dock, especially when subsidized by the federal government, conferred a significant competitive advantage on shipyards large enough to attract major repair work and available smallish building orders during the lean years of the inter-war period and Great Depression. Companies like Burrard Dry Dock rode out economic downturn until government work associated with naval rearmament brightened prospects. (Canadian Merchant Service Guild) to match its growing importance as an international port and transit point, Vancouver was still without major facilities for serving large ocean-going cargo and passenger ships. ${ }^{29}$ A national harbor board based in Ottawa was the responsible authority, but the Canadian federal government withheld funding the full cost of such a major capital project in favor of existing financial assistance extended to private companies. Under the Dry Dock Subsidies Act, Wallace interests, rechristened the Burrard Dry Dock Company, obtained a four percent subsidy to

29 University of Toronto Thomas Fisher Rare Book Library, Toronto, Vancouver Harbour Commissioners, Port of Vancouver, British Columbia (Vancouver, 1925). Agnes Rothery, The Ports of British Columbia: The story of Canada's Great Pacific Seaport Cities Vancouver and Victoria (New York, 1943). Jim Lyon and Barbara Duggan, The Port of Vancouver: Canada's Global Gateway (Vancouver, 1993). 
build a large floating dry dock valued at $\$ 2.5$ million on the shore of North Vancouver. ${ }^{30}$ Once completed, the floating dry dock conferred a near monopoly on repair and servicing of large ships in the port of Vancouver onto the company. In a similar fashion, Yarrows benefited directly from the opening of a large government graving dock at Esquimalt in 1926, to replace the smaller, crumbling graving dock dating from 1887 . The new graving dock, part of a network of others located strategically throughout the British Empire, was big enough to handle the largest warships and passenger liners of the day, thereby serving the purposes of imperial and national defense. ${ }^{31}$ Aside from naval work, Yarrows conducted considerable commercial business when the nearby graving dock was otherwise unoccupied. The company was not burdened with the financial demands of ownership, yet still gained preferential usage on a payment basis due to geographical location. Investments in dry docks set the shipyards at Prince Rupert, Esquimalt, and North Vancouver apart from potential competitors. As other shipyards vanished, the ability to take on ship repair and refit work allowed those shipbuilders left to survive the worst doldrums of depressed business and economic downturn.

The onset of the Great Depression marked the lowest point for the struggling shipbuilding industry on Canada's west coast. In the wake of virtually no new orders for ship construction, companies drastically cut costs and trimmed hours by keeping staffs and workers on a casual basis. Even then, it proved barely enough to get by. Clarence Wallace, who took over as president of Burrard Dry Dock from his father, used some creative financing and connections with British Columbia's rich and powerful to keep the company afloat. $^{32}$ Competition for the little business available intensified. Pacific Salvage Company owned by wealthy Victoria businessman Arthur Burdick set up a yard beside Burrard Dry Dock in North Vancouver, a move apparently aimed at getting some share of the other company's work. ${ }^{33}$ Consequently, relations between the Wallace family and Burdick were never particularly good, if downright hostile at times. Even with his deep pockets, Burdick considered closing the money losing salvage and repair yard until

30 Dry Dock Subsidies Act, R.S.C. 1927, c. 191: see Appendix B for full text. North Vancouver Museum and Archives, North Vancouver (hereafter NVMA), 1925-12, The North Shore Press, "Dry Dock and Harbour Edition," July 1925. Lewis Johnman and Hugh Murphy, "Subsidy and Treasury: the Trade Facilities Act and the UK Shipbuilding Industry in the 1920s," Contemporary British History 22 (March 2008), 98.

31 National Archives of the United Kingdom (hereafter NA/UK), ADM 116/3113, "Memorandum on the Importance of Esquimalt as a Naval Base," October 1926. CFB Esquimalt Naval and Military Museum, Esquimalt, Canada Esquimalt Graving Dock, fonds 8 series D3 box 5, BR 4000(1), British Commonwealth Dock Book vol. 1 Particulars of Graving Docks, Floating Docks and Patent slips in the British Commonwealth.

32 BCA, ms-1230, J.S. Marshall, corporate history of Burrard Dry Dock Company, 1963. Progress: An illustrative presentation by Burrard Dry Dock Company Limited of their war and peacetime shipbuilding facilities in Canada's largest Pacific port, Vancouver, British Columbia, 1894-1946 (Vancouver, 1946).

33 BCA, T2010:0001, oral history interview with Barney Johnson, 28 May 1976. Arthur Burdick ran Pacific Salvage Company with his brother Newton. S.C. Heal, "ITB: A Family Affair," Mariner Life (June 2005), 24. 
a group of employees led by Donald Service approached him about keeping operations going as North Van Ship Repairs Limited, a subsidiary in which they would become part owners. $^{34}$ Whether seeing a renewed business opportunity or merely to spite Wallace, Burdick was receptive enough to the idea to advance sufficient funds for the new company to get by. The underdog North Van Ship Repairs underbid on contracts thought to belong to Burrard Dry Dock, kept labor costs low, and generally did anything possible to obtain business. ${ }^{35}$ Only the technological advantage of the floating dry dock brought the big repair work to Burrard Dry Dock. North Van Ship Repairs also made plans to build larger floating dry docks than its existing 500 ton one, but lacked the capital and a federal subsidy to make the venture worthwhile for the time being. Prominent shipbuilders in British Columbia once again called on the federal and provincial governments to stimulate the industry and the employment that it would generate. ${ }^{36}$ In those lean years, Wallace's Burrard Dry Dock delivered an ice-strengthened arctic patrol vessel for the Royal Canadian Mounted Police and a fireboat for the City of Vancouver, while North Van Ship Repairs built a couple West Vancouver ferries. Though smallish in nature, these construction orders were a harbinger of renewed interest in domestic shipbuilding from the mid-1930s onward to provide warships and government fleet vessels in Canada.

Canada's west coast shipyards strove hard to obtain a fair share of the shipbuilding associated with naval rearmament. In terms of naval forces and establishments, the interwar Royal Canadian Navy was very small and focused around destroyers bought or passed secondhand from the British, two of which were stationed at Esquimalt to protect British Columbia's sea approaches and shipping. Based essentially on British equipment and battle doctrine, Canadian naval forces were intended to form part of a squadron within a larger imperial fleet comprising Australian and New Zealand ships as well. ${ }^{37}$ The main British naval base and dockyard in the Pacific was located in Singapore at the tip of the Malaya peninsula, with a secondary less developed base at British possession of Hong Kong on mainland China. The shipbuilding holiday and limitations on major capital warships imposed by the Washington and London naval treaties on signatory countries, including the United States and the United Kingdom on behalf of the British Commonwealth, came to an end with expiration in 1936. In response to Japan's rising naval strength and aggressive military actions in China, American legislators passed bills to expand and modernize the U.S. Navy with new aircraft carriers, cruisers, destroyers, and submarines, some of which were built in Pacific

34 NVMA, Donald Greenwood, fonds 800 acc. 94-75, Burrard-Pacific News (April 1954), 2.

35 NVMA, William Christie, fonds 944, North Van Ship Repairs Limited time book, JanuaryNovember 1934.

36 NVMA, Matthew T. Davie, fonds 105 file 1C, Burrard Dry Dock Company Limited North Vancouver pamphlet, "The Shipbuilding and Ship Repairing Industry in Canada and its Relation to Unemployment." Library and Archives of Canada (hereafter LAC), RG 19 vol. 528 file 131-5-0, letter Alex Johnston to C.A. Dunning, 8 March 1939.

37 Michael Whitby, "In Defence of Home Waters: Doctrine and Training in the Canadian Navy during the 1930s," Mariner's Mirror 77(May 1991), 170. NA/UK, ADM 1/9483, message Chief of Naval Staff Ottawa to First Sea Lord, 282205 November 1936. 


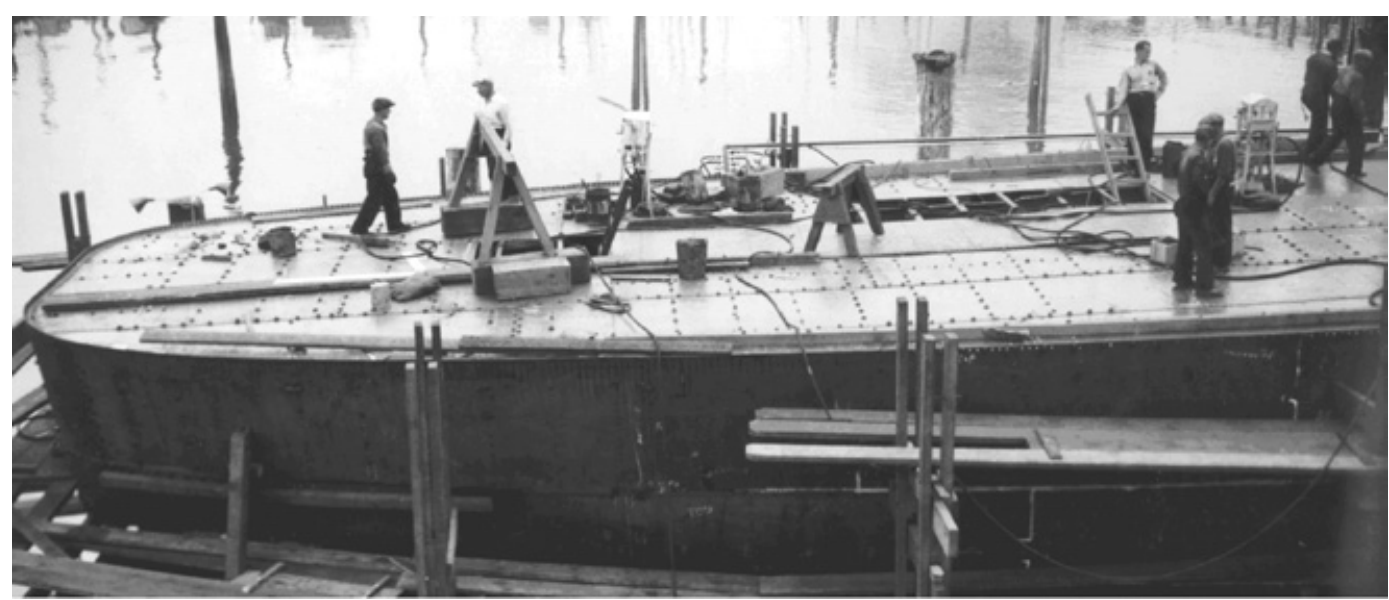

Illustration 3: This early war minesweeper shows clearly the extent of riveting still practiced in construction by Canada's west coast shipyards. Under pressure from procurement authorities, welding increased, but never to the extent used in U.S. wartime shipyards engaged in both naval and merchant shipbuilding. (North Vancouver Museum and Archives Photo No. 9692)

coast navy yards and at private firms. ${ }^{38}$ San Francisco-area shipyards meanwhile received orders from the U.S. Maritime Commission to build standardized merchant ship hulls amenable to conversion as naval auxiliaries and fleet tenders. Like the United States, the Canadian government identified Japan as the most likely military threat and worried about the coastal defense of British Columbia from seaborne attack. ${ }^{39}$ Though certainly modest compared to American naval rearmament, Canada's proposed program represented a major change politically and brought direct business to British Columbia shipyards. Yarrows and Burrard Dry Dock, experienced shipbuilders with the most

38 Dean C. Allard, "Naval Rearmament, 1930-1941: An American Perspective," Revue Internationale d'Histoire Militaire 73(1991), 42-43. William M. McBride, "The Unstable Dynamics of a Strategic Technology: Disarmament, Unemployment, and the Interwar Battleship," Technology and Culture 38 (April 1997), 413. Library of Congress Manuscript Division, Washington D.C., Admiral Emory Scott Land, box 7 file "Building Program," memorandum for Chief of Naval Operations, 28 May 1931. Michael Alle West, "Laying the Legislative Foundation: The House Naval Affairs Committee and the Construction of the Treaty Navy, 1926-1934,” PhD dissertation, Ohio State University, 1980, 332. Charles Vaughn Reynolds Jr., “America and a Two-Ocean Navy, 1933-1941," PhD dissertation, Boston University Graduate School, 1978, 104. John T. Kuehn, Agents of Innovation: The General Board and the Design of the Fleet That Defeated the Japanese Navy (Annapolis, 2008), 177-178. National Council of American Shipbuilders, Commercial Shipyards and the Navy (New York, 1937).

39 Roger Sarty, “"There will be trouble in the North Pacific': The Defence of British Columbia in the Early Twentieth Century," BC Studies 61 (Spring 1984), 28. Galen Perras, "Future plays will depend on how the next one works': Franklin Roosevelt and the Canadian Legation Discussions of January 1938," Journal of Military and Strategic Studies 8 (Summer 2006), 27. John D. Meehan, The Dominion and the Rising Sun: Canada Encounters Japan, 1929-41 (Vancouver, 2004). 
developed facilities and skilled workforces, each received contracts to build coal-burning minesweepers to a British Admiralty design, dubbed the "Fundy" class after the lead ship. ${ }^{40}$ The small minesweeper of limited capabilities, however, signified the first steel warship built in British Columbia for over twenty years. After Canada's declaration of war against Nazi Germany in September 1939, the same two shipyards were tasked to build corvettes, a British designed emergency escort ship adapted from whale catchers, for the Royal Navy and Royal Canadian Navy. ${ }^{41}$ The warship was not technically complex, given that Yarrows and Burrard Dry Dock were probably capable of building destroyers to either British or American design. Instead, orders were placed with Prince Rupert Dry Dock, North Van Ship Repairs, and Burrard Dry Dock for the construction of an improved British designed minesweeper that burned oil instead of coal belonging to the "Bangor" class. ${ }^{42}$ Thanks to national defense procurement, Burdick and his company finally possessed the necessary funds for building floating dry docks, to join the next tier of shipyards chasing further government war contracts. ${ }^{43}$ Serial production of standardized merchant ships and frigates, the next challenges for Canada's west coast shipyards, ensured enough business for everyone.

\section{Tried Practices Meet New Modes of Production}

In due course, shipyards in British Columbia became volume producers of the warships, cargo vessels, and fleet auxiliaries vital to prosecution of global world war and operations on land and sea. The coordinators of this large effort was Canada's Department of Munitions Supply, created in 1940 under federal cabinet heavyweight Clarence Howe, and a single purpose crown corporation named Wartime Merchant Shipbuilding Limited, headed by British Columbia businessman and lumber baron

40 LAC, RG 24 series D-1-b vol. 3840 file 1017-10-17 pt. 1, memorandum Chief of Naval Staff to Minister of National Defence "Proposals for Assistance to Industrial Recovery Shipbuilding Industry," 19 March 1935. NVMA, Versatile Pacific Shipyards Incorporated, fonds 27 series 44 box 210 file "Contract and Specifications of Minesweeper 1937," contract between HM King and Burrard Dry Dock Company, 23 August 1937. Maritime Museum of British Columbia, Victoria, Yarrows Limited, workbook for building HMCS Nootka, 193738.

41 NA/UK, CAB 102/126, F.N. Smith, "History of the British Admiralty Technical Mission in Canada."

42 LAC, Clarence D. Howe, MG 27 III B20 vol. 52 file S-14-2, letter C.D. Howe to Ian Mackenzie, 24 February 1940. LAC, RG 24 series D-1-c acc. 1983/84 167 vol. 3841 file NSS1017-10-22, memorandum D.B. Carswell to C.D. Howe, 5 August 1940. W.A.B. Douglas, Roger Sarty, and Michael Whitby, No Higher Purpose: The Official Operational History of the Royal Canadian Navy in the Second World War, 1939-1943 vol. 2 part 1 (St. Catharine's, 2002), 73.

43 NVMA, Arthur Charlton Burdick, fonds 505, scrapbook "Will Expedite Shipbuilding," Daily Colonist (5 August 1941). UBC/SS, Harvey MacMillan, box 24 file 17, William Dey to Austin Taylor "Report on progress of construction of new Floating Dry Dock at North Van Ship Repairs,” 2 December 1942. 
Harvey MacMillan. ${ }^{44}$ These procurement bodies selected suitable private companies, awarded contracts, controlled payments, and supervised progress on war-related work. The end users of the ships and munitions so produced were Canadian, British, American, and South Asian. ${ }^{45}$ Howe returned from the United Kingdom in early 1941 convinced that Canada could make a significant contribution to the Allied war effort in shipbuilding. Discussions with British and American officials resulted in placement of orders for large numbers of merchant ships from Canada's west coast, where building capacity was still under-utilized by naval commitments. The eventual decision to concentrate naval shipbuilding in Victoria and Esquimalt freed up larger shipyards in the Vancouver area for solely merchant ship construction. ${ }^{46}$ In effect, the Canadian shipbuilding program, particularly in British Columbia, became an adjunct of the massive wartime shipbuilding efforts undertaken by the U.S. Maritime Commission and Navy Department. Canadians followed American business practice, yearned for American-style labor agreements promoting harmony and stability, and drew inspiration from improved production processes and faster mass production techniques. ${ }^{47}$ The scale and traditions of shipbuilding in British Columbia, however, were sufficiently different to create a blended form of production that was in part British rooted and part North American. The technology employed to construct wartime ships on Canada's west coast reflected a curious hybrid.

Riveting persisted much longer as a predominant production method in Canada's west coast shipyards than elsewhere along the Pacific coast. The practice of joining overlapping steel plates together with heated rivets or lugs driven in tight by physical force was proven and widespread. Ships assembled in this fashion were strong enough to meet most situations, but the extra steel and rivet heads added considerable weight that

44 UBC/SS, Harvey MacMillan, box 90 file 13, Notes for talk at 70 th annual meeting Canadian Manufacturer's Association, Seigniory Club, 10 June 1941. Ken Drushka, H.R.: A Biography of H.R. MacMillan (Madeira Park, 1995), 222-223. John de Navarre Kennedy, History of the Department of Munitions and Supply vol. 1 (Ottawa, 1950), 490.

45 Lewis Johnman and Hugh Murphy, "The British Merchant Shipping Mission in the United States and British Merchant Shipbuilding in the Second World War," The Northern Mariner/Le marin du nord 12 (July 2002), 8.

46 LAC, W. Harold Milne, MG 30 B121 vol. 1 file 25, letter W.H. Milne to D.A. Clarke "Yarrows Limited, Esquimalt, B.C.," 16 February 1942. National Archives and Records Administration (hereafter NARA) College Park, RG 178 entry 30 box 6 file 22-6, memorandum "Visit to Canadian Pacific Coast Shipyards," 26 September 1942.

47 Chris Madsen, "American Influence on Canadian Wartime Shipbuilding," in Maochun Miles Yu (ed.), New Interpretations in Naval History: Selected Papers from the Fifteenth Naval History Symposium Held at the United States Naval Academy 2-22 September 2007 (Annapolis, 2009), 35. Frederic C. Lane, Ships for Victory: A History of Shipbuilding under the U.S. Maritime Commission in World War II (Baltimore, 1951). Christopher James Tassava, "Launching a Thousand Ships: Entrepreneurs, War Workers, and the State in American Shipbuilding, 1940-1945," Enterprise \& Society 6(December 2005), 588-600. House Committee on Naval Affairs, Report of Subcommittee of Committee on Naval Affairs on Private Shipbuilding Companies on the Pacific Coast (Washington, D.C., 1943). 
had to be factored into plans and designs. ${ }^{48}$ Many British Columbia shipbuilders apprenticed or trained at established shipyards in Scotland and England; there, riveting was the chief technique used in ship construction from the largest warships and passenger liners down to smaller ships. Immigrant foremen, tradespeople, and workers naturally brought learned skills and attitudes with them to Canada and held to those for their livelihood. ${ }^{49}$ Even Clarence Wallace, Vancouver born to English parents, referred in correspondence affectionately to shipbuilding done in the "Old Country." Of course, Norman Yarrow had direct relations with the family business back on the Clyde, to which he looked for advice and expertise. British practice in riveting was known and practiced. The ships built in British Columbia also derived from British designs, including the tramp steamer North Sands and its improved Victory and Canadian variants. ${ }^{50}$ Blueprints and plans initially came in imperial measurements and called for riveting. Unless considerable

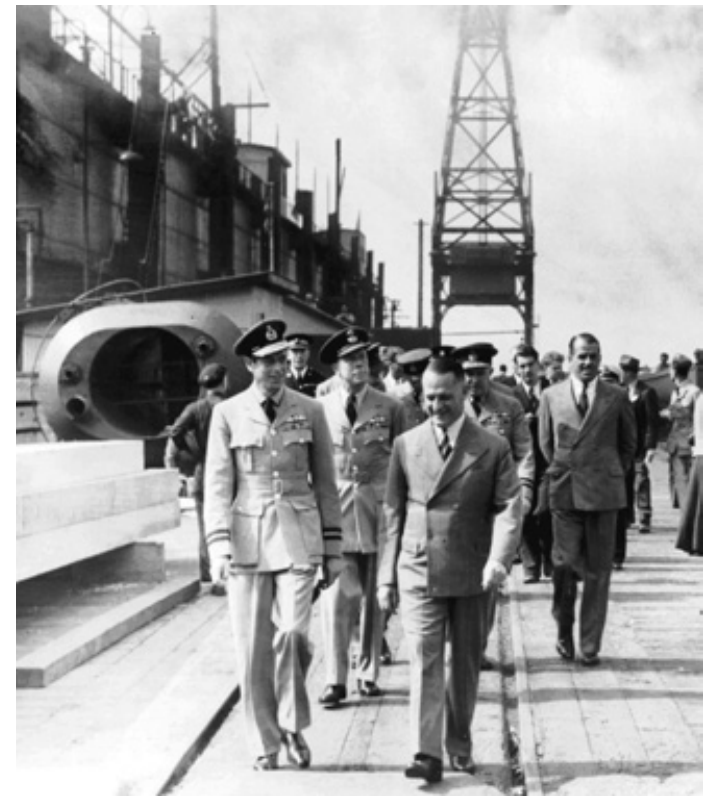

Illustration 4: The always savvy Clarence Wallace, in front on the right, shows a visiting Duke of Kent around the North Vancouver shipyard. Hubert Wallace, immediately back to the right, customarily followed in his brother's shadow. Clarence later became lieutenantgovernor representing the Queen in British Columbia. The floating dry dock towers in the background on the left side. (North Vancouver Museum and Archives Photo No. 27-1193) redrawing was accepted, following the existing plans was quite often easier and left to individual shipyards to decide.

Consequently, new employees entering into the wartime shipyards were frequently trained and taught to rivet from the outset. Gangs of workers were necessary to heat, throw, and pound the rivets during various stages of ship construction; over time, they achieved collectively certain rates of output and quality of workmanship. ${ }^{51}$

48 Lewis Johnman and Hugh Murphy, "Welding and the British Shipbuilding Industry," in Richard Harding (ed.), The Royal Navy, 1930-2000: Innovation and Defence (London and New York, 2005), 90.

49 NVMA, Doug Kinvig, fonds 97 file 1, memoirs, 104. Alastair J. Reid, The Tide of Democracy: Shipyard Workers and Social Relations in Britain, 1870-1950 (Manchester, 2010), 47.

50 S.C. Heal, A Great Fleet of Ships: The Canadian Forts \& Parks (St. Catharine's, 1999), 3943. NA/UK, CAB 102/813, J. Williams, "The U.S. Fort Ships."

51 Hugh Murphy, "The Health of Electric Arc Welders and the Adoption of Arc Welding in the British Shipbuilding Industry, 1930-1951," International Journal of Maritime History 17 
Management attempts to increase the tempo of riveting for the sake of greater production or to break up settled groups met resistance from workers. The controversy over continuous production in British Columbia shipyards that resulted in strikes and a government-appointed royal commission started with Wartime Merchant Shipping trying to tie riveting to paid piecework. ${ }^{52}$ The incentives for departing from one tried practice to another were not always readily apparent. A delegation of British shipbuilders visiting Vancouver-area shipyards observed that riveting was still prevalent, far more than seen in the United States and slightly less so than shipyards in the United Kingdom. ${ }^{53}$ Introduction of pneumatic tools to drive rivets greatly increased speed and cut down on the number of helpers required, but the basic process remained the same. As a technology, riveting was a simple and effective means to build ships quickly and easily taught to the lesser skilled workers recruited by private companies into expanded shipyards. The impetus for moving away from riveting, toward the production process of welding, came mostly from government procurement authorities interested in speedier production and savings in raw material.

Welding was imported into Canada's west coast shipyards from the United States. The Americans were pioneers in applying welding methods to shipbuilding in a big way. ${ }^{54}$ Welding melted steel plates or pieces together through electrical or oxygenassisted flame and heat. Other manufacturing industries had perfected the practice for some time and welding was used in a limited fashion for ship construction and repair prior to the war. Achieving good results in welding required considerable skill and preparation. ${ }^{55}$ It was generally advantageous for companies to train new workers thoroughly in the technique than to retrain older workers with skill and experience levels in other trades. In fact, the occupation typically attracted the large numbers of female

\section{(June 2005), 72.}

52 Chris Madsen, "Continuous Production in British Columbia Shipyards during the Second World War," The Northern Mariner/Le marin du nord 14(July 2004), 5. LAC, RG 27 reel T10186 vol. 268 file 2, "In the Matter of the 'Inquiries' Act and of a Royal Commission to Examine into and Report as to the Most Effective Means of Securing Maximum Production in the Shipyards in the Province of British Columbia: Proceedings of Inquiry," 21 July 1942. Jan Drent, "Labour and the Unions in a Wartime Essential Industry: Shipyard Workers in BC, 1939-1945," The Northern Mariner/Le marin du nord 4 (October 1996), 57.

53 NA/UK, ADM 1/14611, letter First Lord Admiralty to Controller, 9 April 1943. See also LAC, W. Harold Milne, MG 30 B121 vol. 2 file 1 "Report submitted by members of the government delegation appointed by the British Ministry of Labour to study the methods of ship construction in United States, period of tour 14 December 1942 to 5 February 1943." NA/UK, ADM 229/27, "Notes on Merchant Ship Production in the United States of America," 3 November 1942.

54 BL/UC Berkeley, Edgar F. Kaiser, mss. 85/63c series 3 carton 63 file 3, "Oregon Shipbuilding Corporation Portland, Oregon Welding and Cutting Equipment and Supplies," 1940. Christopher James Tassava, "Weak Seams: Controversy over Welding Theory and Practice in American Shipyards, 1938-1946," History and Technology 19 (June 2003), 90.

Rebecca Achee Thornton and Peter Thompson, "Learning from Experience and Learning from Others: An Exploration of Learning and Spillovers in Wartime Shipbuilding," American Economic Review 91 (December 2001), 1363. 
workers finding their way into wartime shipyards.$^{56}$ Industrialist Henry Kaiser was a big promoter of welding for serial ship production in his expansive Oregon and California shipyards. This newcomer to shipbuilding launched ships faster and in greater quantity than many traditional shipbuilders, in large part through the use of innovative techniques. ${ }^{57}$ Canadian procurement authorities under Harvey MacMillan came to believe that similar results were achievable in Canada's west coast shipyards through adoption of welding and other American practices. They visited Kaiser's shipyards and talked with regional U.S. Maritime Commission representatives about the relative advantages and challenges. ${ }^{58}$ Thereafter, government-provided welding technical advisers were assigned to each sizable shipyard building warships and merchant vessels.

The owners and managers in British Columbia's mid-size shipyards were somewhat less keen on the idea. Burrard Dry Dock's second south yard on the Vancouver side of Burrard Inlet was the among the first area shipyards to install American-made Union-Melt appliances. ${ }^{59}$ Welding machines and equipment meant considerable investment of dollars not necessarily recoupable from war contracts or falling under special depreciation allowances. Government expected private companies to pay for the cost of installations and upgrades. As well, welding created whole new classifications of workers in an already crowded shipyard and shop floor space. Jurisdictional disputes between unions over where the welders properly belonged occupied the attention of management in some shipyards and threatened to upset whatever industrial amity existed. At West Coast Shipbuilders Limited, a newer wartime shipyard engaged in merchant ship construction at the former Coughlan site on False Creek, the welders asserted independence from the boilermaker union and dealt with the union-adverse company

56 Carole Paula Thornton, "Women of the Victoria Shipyards 1942-1945: An Oral History," MA thesis, University of Victoria, 1998. Hugh Murphy, "From the Crinoline to the Boilersuit: Women Workers in British Shipbuilding During the Second World War," Contemporary British History 13(Winter 1999), 93-95. Deborah Ann Hirshfield, "Rosie also welded: Women and Technology in Shipbuilding during World War II," PhD dissertation, University of California Irvine, 1987. Amy Kesselman, Fleeting Opportunities: Women Shipyard Workers in Portland and Vancouver during World War II and Reconversion (Albany, 1990), 19.

57 BL/UC Berkeley, Henry J. Kaiser, mss. 83/42c series 15 carton 287 file 13, booklet Richmond Shipyards (30 June 1943). Christopher Tassava, "Multiples of Six: The Six Companies and West Coast Industrialization 1930-1945," Enterprise \& Society 4(March 2003), 15. Emory Scott Land, Winning the War with Ships (New York, 1958), 170-171. Mark S. Foster, Henry J. Kaiser: Builder in the Modern American West (Austin, 1989), 82. Stephen B. Adams, Mr. Kaiser Goes to Washington: The Rise of a Government Entrepreneur (Chapel Hill, 2009). Albert P. Heiner, Henry J. Kaiser American Empire Builder: An Insider's View (New York, 1989), 117-123. Stephen Budiansky, "The Shipbuilding Impresario of California," World War II 22 (November 2007), 29.

58 NARA San Bruno, RG 178 entry 2 box 2 file "Reading File June-July 1942," letter C.W. Flesher to H.R. MacMillan, 28 July 1942.

59 NVMA, 1942-12, "New Process of Welding Speeds Building Ships," North Shore Press Industrial and Commercial Annual, September 1942. George N. Edwards, Waterfront to Warfront: Burrard Dry Dock Company during World War II (North Vancouver, 1995). 
management directly. ${ }^{60}$ Welding indeed represented the future in shipbuilding, but convincing skeptical traditional shipbuilders to assume the risk and associated costs when lucrative contracts guaranteed easy money was a hard sell. Clearly, no shipbuilder in British Columbia was a Henry Kaiser. These shipyards were mid-size, commonly family run or financed, and held to established views of the business and production process. ${ }^{61}$ Innovation and acceptance of newer technology was gradual and measured to fit the circumstances of individual shipyards.

Eventually, pre-fabrication meant that a fair proportion of the work was done outside of the shipyard or in shops adjacent to building ways. British Columbia shipbuilders sub-contracted the production of component parts to other companies locally and farther afield in Canada and the United States. ${ }^{62}$ Marine engines and internal machinery were typically fabricated in specialty shops and then shipped to shipyards for installation. British designs and preference called for steam reciprocating engines, with large boilers, condensers, and scores of metal tubing. ${ }^{63}$ This older, proven technology was within the capabilities of most existing Canadian manufacturers in the marine field. Diesel engines, another alternative, had been used in smaller warships, landing craft, and submarines as well as commercial craft. Vivian Engine Works Limited, a leading manufacturer of marine diesel and gasoline engines in Vancouver, expanded its plant capacity and workforce to meet anticipated wartime demands. ${ }^{64}$ Official Canadian interest in advanced diesel engines for maritime purposes, however, never compared to ambitious wartime programs by the U.S. Navy and U.S. Maritime Commission. Private companies pushing the newer technology could not count on government encouragement, as steam reciprocating engines remained predominant in Canadian-built wartime ships due to British preference. ${ }^{65}$ Auxiliary machinery likewise closely followed British designs adapted to North American manufacturing practice. Two companies in Vancouver suburb New Westminster, Westminster Iron Works and Heaps Engineering, made motorized

60 Chris Madsen, "Organizing a Wartime Shipyard: The Union Struggle for a Closed Shop at West Coast Shipbuilders Limited 1941-44," Labour/Le travail 65 (Spring 2010), 94-95.

61 Stephen Leacock and Leslie Roberts, Canada's War at Sea (Montreal, 1944), 119.

62 City of Toronto Archives, Toronto (hereafter CTA), John Inglis Company, fonds 1297 series BI box 66(196607) file 37, "Resume of Ordnance, Naval and Marine Production 19381945."

63 NA/UK, CAB 102/530, S. McKenna, "Production of Naval Machinery 1935-1945." CTA, John Inglis Company, fonds 1297 series A5 box 21(196598) file "Visits to Other Plants 1942-43," memorandum John Findlay to James McKenzie "Trip to West Coast, January 1942, principally in connection with Trial of HMCS Timmins at Yarrows Limited, Victoria," 3 February 1942.

64 City of Vancouver Archives, Vancouver (hereafter CVA), M10068, clipping file "Vivian Engine Works Limited," "Vancouver-Made Diesels Have Gained World-Wide Reputation" (28 April 1942). Denis Griffiths, "British Marine Industry and the Diesel Engine," The Northern Mariner/Le marin du nord 7 (July 1997), 25.

65 NA/UK, ADM 1/15340, "Visit of Merchant Shipbuilders \& Marine Engineers to U.S.A. and Canada, November, 1942," 30 December 1942. 


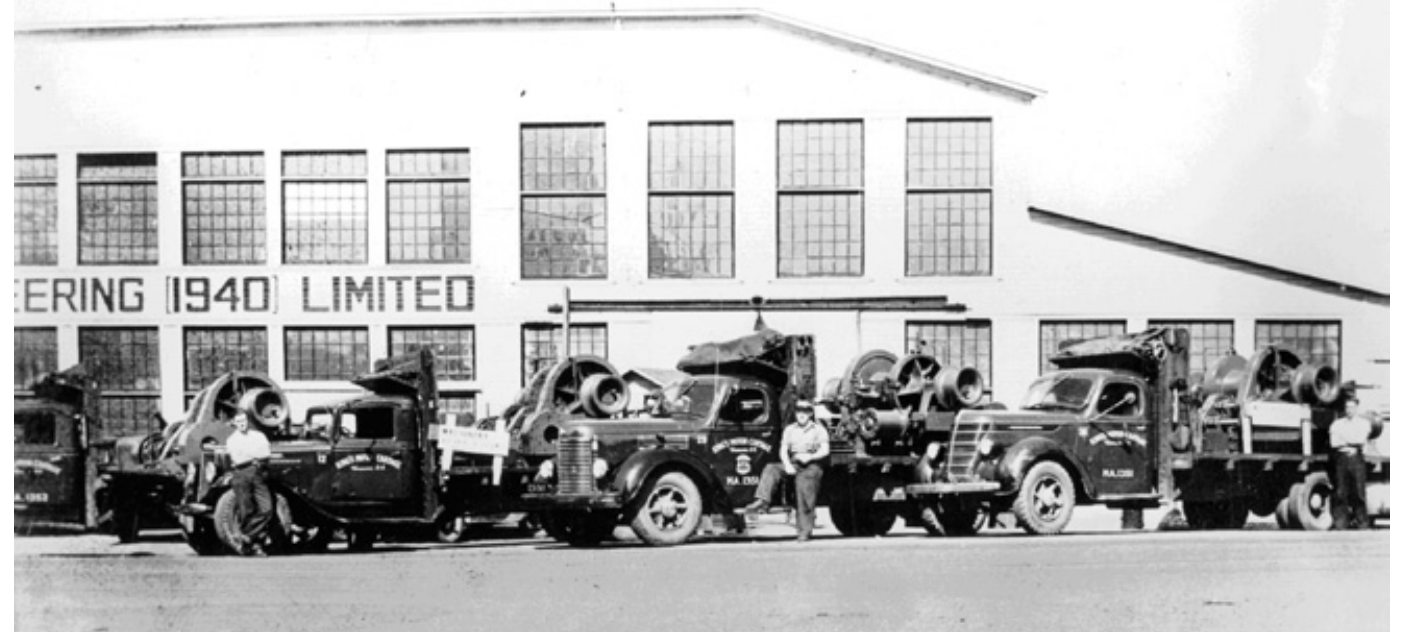

Illustration 5: Windlasses manufactured by Heaps Engineering (1940) Limited loaded onto flatbed trucks for delivery to nearby Vancouver shipyards to meet progress schedules. Wartime saw more extensive use of sub-contracting to industrial firms and pre-fabrication of components in British Columbia's Lower Mainland. (New Westminster Public Library)

winches and anchor windlasses in expanded wartime plants. ${ }^{66}$ These items were then stored until shipped to designated shipyards when ships neared completion. West Coast Shipbuilding contracted sister company Hamilton Bridge to fabricate large bulkheads and upper ship parts positioned into place by cranes on building ways. ${ }^{67}$ Burrard Dry Dock and North Van Ship Repairs employed a similar system, but to a lesser extent due to the constraints of geography and crane lifting capacity. The staging of sequenced concurrent building and fabrication became hugely important. Yarrows, by now entirely devoted to naval warship construction, focused on building revised twin screw corvettes called frigates. The revised frigate, taken from the British and redrawn by the Americans, was an escort ship for convoy work and anti-submarine warfare incorporating an all-welded design and considerable pre-fabrication. ${ }^{68}$ This mode of production allowed for faster completion and delivery by lesser skilled workers.

Canada's west coast shipyards produced ships in quantity and in record times, perhaps not to the extent of Kaiser and some U.S. shipbuilders, but a fine achievement for a local industry that grew from very modest beginnings a mere three years previously. ${ }^{69}$

66 New Westminster Public Library, New Westminster, "Heaps Engineering (1940) Limited: Outline of the History, Physical Assets and Operation." Westminster Iron Works Company Limited (Vancouver, 1944).

67 T.A. McLaren and Vickie Jensen, Ships of Steel: A British Columbia Shipbuilders Story (Madeira Park, 2000), 59.

68 LAC, RG 24 series D-1-c acc. 1983-84/167 vol. 3797 file 8200-382, letter Secretary Naval Board to Canadian Vickers, Yarrows, Morton Engineering, Davie Shipbuilding, Davie \& Sons "CN 635-663," 24 July 1943.

69 James Houlihan, Western Shipbuilders in World War II (Oakland, 1945), 37-39. Oregon Shipbuilding Corporation, Record Breakers (Portland, 1945). BL/UC Berkeley, California 
The emphasis on numbers lessened as the contest for convoys in the Atlantic turned in Allied favor and North American factories filled the supply routes to theaters of operations. For the first time, new ship construction surpassed sinkings. The high point

for shipbuilding business and shipyard employment in British Columbia was late $1943 .{ }^{70}$ The nature of work in the shipyards turned to conversion and finishing work for fleet and specialty vessels required for the war against Japan.

\section{Outfitting and Finishing}

The continuing war with imperial Japan saved Canada's west coast shipyards from a sudden decline in business. Harvey MacMillan and procurement authorities slowed down, deferred, and canceled further contracts for cargo vessels and escort-type warships. The likelihood of obtaining additional naval business in lieu was remote because the Royal Canadian Navy still preferred to get its larger warships such as cruisers, light fleet carriers, and fleet destroyers from the United Kingdom. ${ }^{71}$ British freebies and bargain deals undoubtedly sweetened the choice, but it was doubtful whether any Canadian west coast shipbuilder at the time possessed the expertise or the technical capability to build such complicated warships. The important point is that Canadian companies were not even given the opportunity to prove that they could rise to the occasion. Thus, the domestic shipbuilding industry derived little lasting benefit from participation in the big wartime emergency programs on behalf of the government going into the future. Despite heightened expectations, the Canadian federal government declined to make any firm commitments, financial or otherwise, in regard to fostering the business beyond the contracts already placed and completing. In the interim, Canada's west coast shipyards became engaged in work for the British Admiralty converting redundant merchant ship hulls into fleet support and maintenance ships and constructing tank landing ships modified to be transport ferries destined for employment in the Pacific and Indian Oceans. ${ }^{72}$ The situation was rather fortuitous: British shipyards were brimming full with available work; Canada generously offered to pay for the work through Mutual Aid as the United States tightened down on expenditures of Lend-Lease funds; British Columbia's geographical location on the Pacific closer to active theaters of operation was convenient; and, few people wanted to see large-scale lay-offs amongst

Shipbuilding Corporation, Calship: An Industrial Achievement (San Pedro, 1947).

70 Dominion Bureau of Statistics, Annual Industry Report: The Shipbuilding Industry 1943 (Ottawa, 1944).

71 W.A.B. Douglas, Roger Sarty, and Michael Whitby, A Blue Water Navy: The Official Operational History of the Royal Canadian Navy in the Second World War, 1943-1945, vol. 2 part 2 (St. Catharine's, 2007), 512. University of Toronto Archives, Toronto, Vincent Massey, B87-0082 box 312, diary entry, 10 January 1944.

72 National Maritime Museum, Greenwich, Vice Admiral James Wilfred Dorling, JOD/185/2, diary entry, 18 February 1944. NA/UK, CAB 120/276, telegram Prime Minister to First Lord and First Sea Lord commenting upon "Provision of Shipping for the Supply and Maintenance of the Fleet in the War against Japan," 10 March 1944. Directorate of History and Heritage, National Defence Headquarters, Ottawa, fonds 81/520 series 13 file 1650-1, message Admiralty to Commander-in-Chief British Pacific Fleet, 011130 January 1945. 
workers in shipbuilding and the immediate economic impact it would have on local Vancouver and Victoria communities. In effect, the additional Royal Navy work allowed Canada's west coast shipyards to ease off production whilst keeping progressively fewer employees occupied. For the duration of the war, British Columbia served as a rear base combining production and repair facilities at the call of the British Admiralty. Esquimalt naval base and its strategic graving dock were identified for refits of cruisers and below and if necessary, follow-on battle damage repairs to ships returning from advance naval bases. ${ }^{73}$ Canada's west coast shipyards and associated industrial firms performed this last war task using an assortment of technical novelties.

Electrical work for the naval auxiliaries incorporated the best North American practices while accommodating British specifications as the ultimate end user. Canada's electrical manufacturing industry was relatively well-advanced. ${ }^{74}$ Canadian General Electric and Canadian Westinghouse, the two biggest competitors back east, were subsidiaries of American parent companies. British Columbia companies, by contrast, were home-grown and extremely entrepreneurial. ${ }^{75}$ The largest electrical contractor in western Canada was Hume \& Rumble Limited, a New Westminster enterprise that started in radios and branched out into work on hydro-electric dams, high voltage electric lines, and other big industrial projects in the province. Mott Electric, another notable electrical contracting firm, wired road lighting and office buildings. Shipyards sub-contracted most complex jobs to outside electrical firms able to meet exacting requirements. The maintenance ship was essentially a floating workshop filled with tools and machines necessary to fix whatever was needed on the spot far away from bases. The corresponding power draw was higher than normal self-contained ships. Electrical contractors installed generators, fans, fuse boxes, and switches as well as heavy wiring throughout ship hulls. Indeed, the nature of work shifted from simple assembly to elaborate finishing requiring specialized skills and equipment. Lists of electrical items meeting Admiralty specifications from suppliers were comprehensive. ${ }^{76}$ Besides the usual distinction between alternating and direct current devices, standard British voltage was

73 NA/UK, ADM 1/18075, message British Admiralty Technical Mission Ottawa to Controller, 272000 February 1945. LAC, RG 24 series D-1-c vol. 8150 file NSS1655-14, "Minutes of meeting held at NSHQ at 1500, March 21, 1945 between representatives of the British Admiralty Technical Mission, in order to discuss problems arising from the Admiralty intention to keep one cruiser and two destroyers continuously under refit on the West Coast of Canada during the war in the Pacific."

74 McMaster University Archives, Hamilton, Canadian Westinghouse Company, series 3 box 16 file 4, John Brittain, typescript history of the Canadian electrical industry. Hamilton Public Library, Hamilton, Canadian Westinghouse Company Limited "50 Years of Progress with Canada 1903-1953," 1953. Toronto Reference Library Baldwin Reading Room, Toronto, Canadian General Electric Company Limited "Electricity and Canada's War Effort."

$75 \mathrm{UBC} / \mathrm{SS}$, Leon J. Koerner, box 5 file 7, Industrial British Columbia 1945 (Vancouver, 1945). Development of hydro-electric power generation in the province fostered private firms. G.W. Taylor, Builders of British Columbia: An Industrial History (Victoria, 1982), 182.

76 NVMA, Wartime Shipbuilding Limited, fonds 143 file 7, Schedule of electrical fittings "Maintenance Vessels," 6 December 1944. NA/UK, ADM/17219, "Methods of Protection of Electrical Equipment," 23 December 1943. 
different than that pertaining in North America. Consequently, installation involved more than just taking common commercial items off the shelf. Batches of electrical components were custom-made, tested, and inspected for higher voltage requirements and naval usage. ${ }^{77}$ Electrical manufacturers and contractors made improvements where possible, but standardization to approved plans remained imperative. Spare parts to remove and replace worn out or blown ones often came from the United Kingdom instead of from North American sources. ${ }^{78}$ Certainly, Canadian electrical manufacturers rarely kept production runs open beyond initial inventories of spares going into the ships prior to departure for operational duties. The fleet support ships, like the warships which they serviced, were then dependent upon stocks in bases and distribution centers. Outfitting of those ships built in Canada's west coast shipyards extended to multiple companies and firms engaged in specialized lines of business.

The application of paint to ship surfaces by the spray method became widespread in wartime shipyards. In the maritime environment, layers of paint protected metal from rusting, salt corrosion, and weathering elements. Painting done by brush and roller, the traditional way, was slower and labor intensive. Spray painting sped up the process by applying paint mechanically through a nozzle under pressure. The method allowed larger surfaces to be covered in a shorter period of time and increased evenness and consistency. Much good paintwork depended upon surface preparation prior to painting, the skill of the individual painter or squad, and weather conditions for proper drying. Shipyards employed painters on payrolls and held sub-contracts with commercial painting

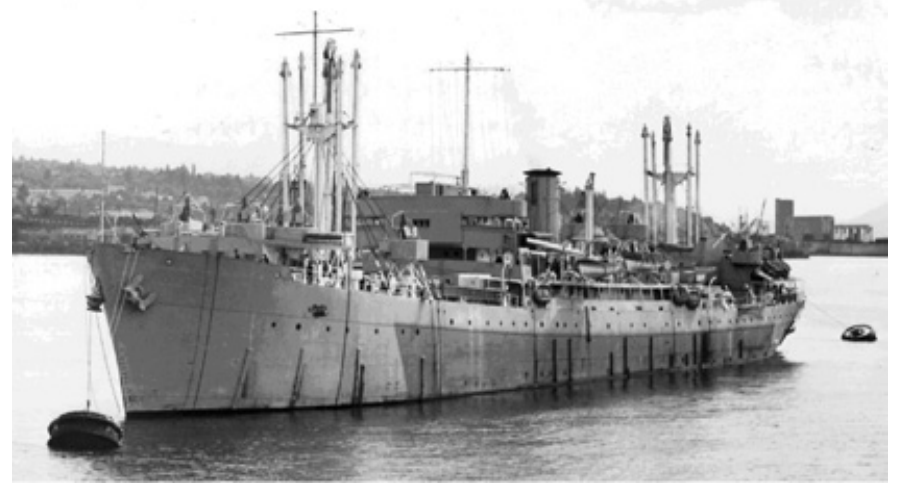

Illustration 6: HMS Mull of Galloway, a maintenance ship completed at North Van Ship Repairs for the Royal Navy in 1945, sporting a late war Admiralty camouflage scheme. Outfitting of these fleet support ships built upon experience in wartime cargo vessel construction and involved considerable finishing work, particularly on the electrical and mechanical sides. (Madsen) companies working in the building trades and construction industry such as J. Boshard and Son Limited, a family business founded by a Dutch immigrant to Vancouver that grew into amongst the largest such enterprises in western Canada. North Van Ship Repairs, Burrard Dry Dock, and West Coast Shipbuilding at various times engaged squads of Boshard spray painters. ${ }^{79}$ Comparability in paid wage rates between the building trades and the

77 NA/UK, CAB102/532, D. McKenna, "Electrical Engineering Items including Fire Control Gear."

78 NA/UK, ADM 116/5808, memorandum “Ship's Spares," 17 May 1943.

79 CVA, International Brotherhood of Painters and Allied Trades Union Local 138, add. mss 304 vol. 10 minute book, executive committee meeting, 3 June 1943. 
shipyards, wherein the federal government dictated wage rates instead of the market, was a leading issue. Known health hazards associated with spray painting, mainly involving skin conditions and lung disease, were also dealt with by companies and government inspectors to a limited extent. ${ }^{80}$ Better masks, regular medical examinations, and improved ventilation were instituted. Still, the perils of spray painting were left to the individual companies and workers to decide. Spray painting was definitely faster than traditional methods, and generally gained widespread acceptance. Warships and merchant vessels previously wore all sorts of patterned camouflage, though the fleet support ships adopted the late war Admiralty scheme of light grey with a darker strip of sea blue running down the hull along the waterline just backward of the bow. ${ }^{81}$ The refinement of radar and sonar lessened the impact of painted camouflage because ships beyond the horizon were visible on screen and tracked by operators, though strict adherence to standards in naval painting was maintained: default colors were shades of grey and blue. The thermal dampening effects of paint were also important for crew livability and the heat signature of a warship against infra-red detection. As soon as any ship left the shipyard, paint coatings began to fade, deteriorate, and flake. Scraping and repainting on ships was a regular feature of maritime life. The quality of the first application of base primer and color layers, commonly by the spray method, relied much on the workers and businesses engaged. Shipyards and firms with reputations for good attention to detail in finishing work obtained the skills and proper equipment to perform specialty services like spray painting. Following the war, the ability to undertake such work in British Columbia became concentrated around a select few shipyards.

The immediate postwar period foreshadowed reduction and consolidation in business affairs amongst Canada's west coast shipyards. In the wake of Japan's unconditional surrender after dropping of atomic bombs on two Japanese cities, the Canadian government invoked cancellation clauses in contracts and ordered shipyards to stop work immediately on all pending wartime orders. The British Admiralty negotiated the completion of several maintenance ships and transport ferries in advance stages of construction, subject to a wider settlement with the United Kingdom over war debts. ${ }^{82}$ Remaining partial hulls, components, and materials were deemed surplus and put out for

80 LAC, RG 27 reel T-10094 vol. 90 file 423.2.10, "Report of the Dobson Committee on the Vancouver Shipyards," July 1943. NARA College Park, RG 178 entry 86 box 379, "Summary of U.S. Navy, U.S. Maritime Commission and War Shipping Administration Industrial Health Program in Shipyards of the West Coast Region," 25 September 1945.

81 Admiralty, Naval Staff, Training and Staff Duties Division, C.B. 3098, The Camouflage of Ships at Sea, May 1943. Peter Hodges, Royal Navy Warship Camouflage 1939-1945 (London, 1973), 41.

82 LAC, Clarence D. Howe, MG 27 III B20 vol. 41 file S-9-25(2), memorandum D.B. Carswell to C.D. Howe "Admiralty Vessels," 20 August 1945. Queen's University Archives, Kingston, William Clifford Clark, collection 2207 box 15 file "UK Financing Arrangements Post V-J Day Discussions September 1945," Department of Munitions and Supply press release no. 586A. LAC, RG 19 vol. 414 file 101-106-2E, telephone message for R.B. Bryce, 1 March 1946. Chris Madsen, "Dollars, Diplomacy and Fleets: John Maynard Keynes and Stage II Naval Requirements for the War against Japan," International Journal of Maritime History 14 (June 2007), 138. 


\section{BRITISH COLUMBIA BUILDS SHIPS}

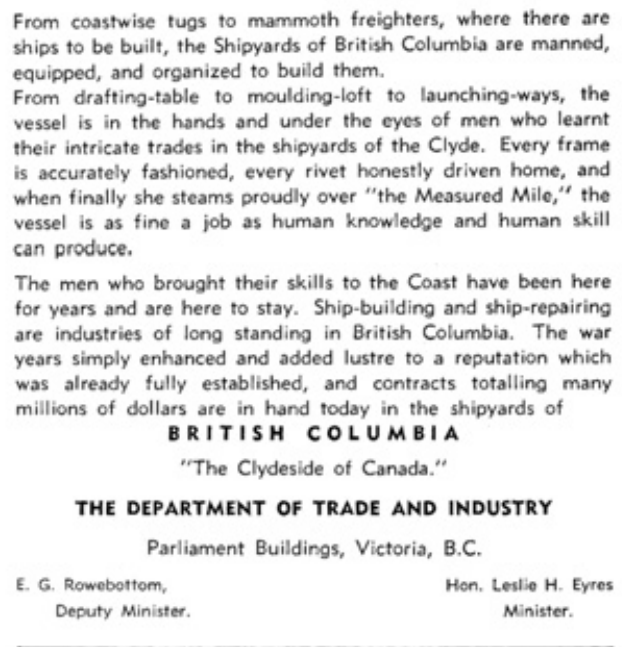

Illustration 7: A 1946 provincial advertisement plays upon supposed British roots and comparisons in making potential customers aware of the shipbuilding capacity developed on Canada's west coast. In reality, the transition from public to private orders denoted a sharp drop in business, and many owners decided to company. (Canadian Merchant Service Guild) get out leaving the field eventually to just one

disposal to the highest bidder. In this fashion, British Columbia shipbuilders obtained some work by new owners converting ships originally intended for naval use to other purposes as forestry barges and adapted ferries for coastal service. Almost completely lacking were orders for new construction because existing ships and hulls could be obtained for a cheaper price and the government was no longer the primary customer. ${ }^{83}$ The commercial marketplace dictated what business was available, and it was not much. Some shipping companies went back to buying from foreign sources, while others eyed cautiously bottom lines before considering any replacements or additions to fleets minus clear policy from government. ${ }^{84}$ The great unanswered question of course is why Canada's west coast shipyards were so singularly unsuccessful in obtaining more Canadian private business after the wartime experience?

Many shipbuilders just cashed out when the going was still good. West Coast Shipbuilders had already sold off the buildings and yard on False Creek at a fair price factoring in accumulated war profits and capital depreciation. Canadian National Railways closed the Prince Rupert shipyard and sold the dry dock for tow to Seattle. The Wallace family bought Norman Yarrow's shares for $\$ 393,524.90$ covering his interest in Yarrows exclusive of land, property and readjustments with the government. ${ }^{85}$ Whether a rare opportunity to eliminate a rival

83 Maritime Museum of the Great Lakes, Kingston, Canada Steamship Lines (Davie Shipbuilding and Repairing Company) Corporate, series BII box 24A42(993.2.22) file 12.9, letter Angus McGugan to R. Brock Thomson, 17 October 1945. LAC, W. Harold Milne, MG 30 B121 vol. 1 file 2, "Brief for Shipbuilding, with recommendations by the Canadian Shipbuilding and Ship Repairing Association," 28 July 1944. Michael A. Hennessy, "The Fall and Rise of Free Enterprise: State Intervention in Canadian Shipbuilding, 1945-1966," Journal of the Canadian Historical Association 2(1991), 151-152.

84 Michael A. Hennessy, "Postwar Ocean Shipping and Shipbuilding in Canada: An Agenda for Research," The Northern Mariner/Le marin du nord 1(July 1991), 26.

85 NVMA, Versatile Pacific Shipyard Incorporated, fonds 27 series 16 box 50 file U1160, receipt Norman Yarrow to Burrard Dry Dock, 5 August 1947. 


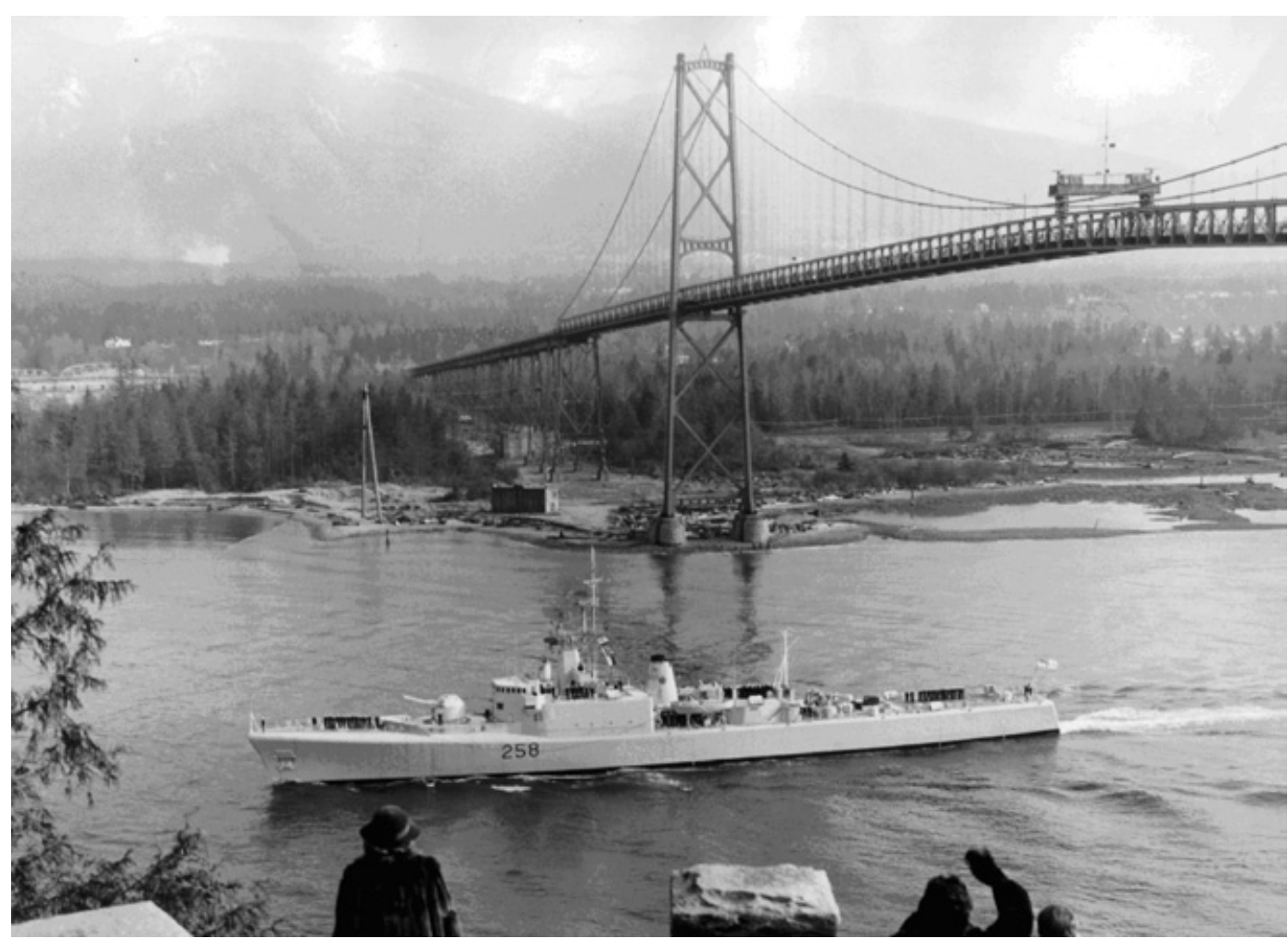

Illustration 8: One of four destroyer escorts started by Burrard Dry Dock in the early 1950s, HMCS Kootenay, leaving Burrard Inlet underneath Vancouver's Lion's Gate bridge. The warships, though a troubled contract for the government in terms of costs and delays, advanced the company's reputation with the Royal Canadian Navy for domestic-sourced shipbuilding. (Madsen)

competitor or a genuine attempt to add capacity, the strategic business decision positioned Burrard Dry Dock as British Columbia's leading shipyard. The wartime south yard in Vancouver proper was closed down and all activities split between the remaining North Vancouver and Esquimalt locations. Burrard Dry Dock finished work on small China coaster freighters, built one government-financed cargo freighter with diesel engines for Canadian National Steamships Line, and brazenly secured an order for eleven coal-carrying ships (out of a contract for fifteen) from the Canadian Export Board on behalf of France. ${ }^{86}$ These ships still reflected a mix of riveted and welded construction. Further government orders came for an all-welded Department of Transport tender and lighthouse supply vessel for service on the British Columbia coast and anti-submarine destroyer escorts of Canadian design for the Royal Canadian Navy. The latter suffered from time delays, cost over-runs, and block obsolescence. When eventually finished, the

86 Michael A. Hennessy, "World War II and the Rebirth and Death of Canada's Merchant Marine," Journal of the Canadian Historical Association 6(1995), 229. Roland Webb, Yarrows Ltd. And Burrard Dry Dock \& Shipbuilding Ltd. Yard Hull Numbers (Victoria, 1993). 
Canadian-made destroyer escorts were not fast enough to track and hunt their primary prey, Soviet nuclear submarines. Burrard Dry Dock was just fortunate to receive the naval order in the first place which solidified its standing in the small stable of shipyards nation-wide devoted to specialized warship construction in the coming Cold War. ${ }^{87}$ Pacific Dry Dock, the ambitious reiteration of North Van Ship Repairs, tried to compete commercially for awhile, but Arthur Burdick eventually decided to sell out the property and contents to its larger neighbor. Through yet another strategic purchase, Burrard Dry Dock emerged as the largest and sole remaining steel shipyard on Canada's west coast, little more than five years after the end of the Second World War. ${ }^{88}$ And still there was not enough business without government support to sustain the shipbuilding capacity that remained.

\section{Conclusion}

Writings on Canadian shipbuilding generally herald the success - daresay the "miracle" - of the Second World War experience. From very modest beginnings, Canada used its industrial potential to expand an industry that produced emergency naval and merchant ships in volume, third in quantity of production only to the United States and the United Kingdom. Canada's west coast shipyards contributed significantly to this admirable achievement. True, the standardized merchant ships were not particularly sophisticated, the warships were no larger than the escort-type frigate, and the naval auxiliaries were actually for another foreign navy. The intensive period of wartime shipbuilding cannot be divorced from the wider context of the fundamentals facing British Columbia shipbuilders over the first three decades of major ship construction from the last years of the First World War up to the beginning of the Cold War. In the main, Canada's west coast shipyards utterly depended upon government orders and encouragement. Prosperity came with war and other public expenditures for maritime uses, while business quickly fell off when those incentives were not present. Consequently, the number and size of shipyards tracked government involvement and interest in shipbuilding, provincially and federally. Most shipyards in Vancouver, Victoria, and Prince Rupert were predominantly sole proprietor, family-established, or subsidiary mid-size private concerns, neither too small to take advantage of economies of scale nor too large to be uncompetitive with too much capacity for available business. Owners grew and contracted business to meet existing demand for ships, even to the point of deciding when to enter or leave the shipbuilding field altogether.

Technology naturally was a crucial means to meet customer expectations, keep pace with the latest production techniques, and position a shipyard to be as competitive as

87 Michael A. Hennessy, "The Rise and Fall of a Canadian Maritime Policy, 1919-1965: A Study of Industry, Navalism and the State," PhD dissertation, University of New Brunswick, 1995, 227. Lewis Johnman and Hugh Murphy, "The Rationalisation of Warship Building in the United Kingdom, 1945-2000," Journal of Strategic Studies 24(September 2001), 108110.

88 Roland H. Webb, "Burrard Drydock Co. Ltd.: The Rise and Demise of Vancouver's Biggest Shipyard," The Northern Mariner/Le marin du nord 6(July 1996), 6. 
possible against rivals. It underpinned key decisions such as whether to focus on wood or more complicated steel construction, acquisition or access to dry docks and other expensive yard equipment, the persistence of riveting as a production process when welding and pre-fabrication became more commonplace, and the final stages of completing ships by way of outfitting and finishing work. Canada's west coast shipyards straddled a middle ground between a high regard for the craftsmanship of British roots amongst owners and workers alike and distinctly industrial processes on a North American model. Sometimes conditional or delayed acceptance of newer technology was the direct result. In this respect, British Columbia shipbuilders struggled to keep abreast of the latest production processes used elsewhere on the Pacific coast in U.S. shipyards. Canada's west coast shipyards were modest affairs compared to those of Henry Kaiser for example, though the types of ships built and imported influences in production technique were similar enough. Certainly, officials such as Harvey MacMillan liked to think big and pushed innovation whenever possible in the wartime program.

Even at its height, shipbuilding in British Columbia struggled to establish a sustainable basis on which it could be assured enough business - more private than government - to keep more than a handful of shipyards commercially viable and operating. Burrard Dry Dock's rise to be the pre-eminent shipbuilder in the province was really the end of an era, in which competing local companies shared in the belief that shipbuilding could be a profitable and worthwhile endeavor if they could just stay current and up-to-date with the technology. During that time, ships were built reasonably well and at times in quantity. In the decades afterwards, shipbuilding in British Columbia went through more swings in both the economic cycle and active government interest in the industry. It was more than just a matter of steady decline in business related to the fortunes of any one company. Seaspan Marine Corporation's securing of a major commitment from government for construction of public fleet ships, to the tune of $\$ 8$ billion over the next two decades, marks return to an old pattern. The business fundamentals still remain the same. Given enough public largesse, miracles can occasionally happen.

Research for this paper was made possible with funds from a standard research grant from the Social Sciences and Humanities Research Council of Canada and Canada's Department of National Defence. 


\section{Appendix A: the British Columbia Shipping Act.}

"An Act respecting Shipping and to make Provision for Aid to the Shipbuilding Industry in the Province of British Columbia," Statutes of British Columbia 1916, chap. 57 (royal assent given on 31 May 1916)

His Majesty, by and with the advice and consent of the Legislative Assembly of the Province of British Columbia, enacts as follows:-

\section{Short Title}

1. This Act may be cited as the British Columbia Shipping Act.

\section{Interpretation}

2. In this Act, unless the context otherwise requires, the following expressions shall include the meanings hereby assigned to them, that is to say:-

"Minister" means the Minister of Finance, and shall include his deputy and any person for the time being lawfully acting in that capacity;

"Auditor General" means the Auditor General of British Columbia;

"Ship" shall include every description of vessel hereafter constructed in the Province of British Columbia and used for the carriage of freights on ocean routes, and shall not include any vessel intended for use in Provincial coastwise or inland waters trade; provided that construction thereof be commenced and completed within 12 months from the coming into force of this Act, or within such further time or times as may be fixed in and by an Order or Orders in Council pursuant to recommendation of the Commission;

"Commission" means the Shipping Credit Commission constituted in and by this Act;

"Superintendent" means the Superintendent of the Commission and any person for the time being acting in that capacity;

"Property" includes all real and personal estate and property of every kind and nature whatsoever, including choses in action;

"Securities" means every security, bond, debenture and, and obligation issued by the Commission under the provisions of this Act;

"Mortgage" shall include every security taken by the Commission under the provisions of this Act;

"Loan" means loan made by the Commission under the provisions of this Act;

"Regulations" means regulations for the time being in force under this Act;

"Prescribed" means prescribed by this Act or by regulations.

\section{Application of Shipping Acts}

3. The provisions of the Merchant Shipping Act 1894, and of the Canada Shipping Act and all amendments thereto and re-enactments thereof from time to time shall govern the Commission in the carrying-out of the provisions of this Act, and every power by this Act conferred upon the Commission shall be deemed to be such a power as may lawfully be conferred upon the Commission and exercised by the Commission in conformity with the 
provisions of the said Merchant Shipping Act 1894, and the Canada Shipping Act and all amendments thereto and re-enactments thereof as aforesaid; and in relation to ships the Commission shall have and may exercise every power and right which an individual and an incorporated company, and a ship owner and an owner of shares in a ship, and a managing owner of a ship or ships and a ship's husband, and a mortgagee of a ship and a mortgagee of shares in a ship as or may have or lawfully can or may exercise under and by virtue of the provisions of the said Merchant Shipping Act 1894 and the Canada Shipping Act, and of any other law or Statute for the time being having the force of law in the Province of British Columbia.

\section{Loans for Shipping Purposes Division (1) - Administration Shipping Credit Commission}

4. (1). There is hereby constituted a Commission for the administration of this Act, to be called the "Shipping Credit Commission," which shall consist of a Superintendent and two other Directors, and which shall be a body corporate, with perpetual succession and a common seal, with power to contract and be contracted with, sue and be sued, plead and be impleaded, and to stand seized of, hold, purchase, let, lease, and alienate property, and to do and perform all such things and acts as a corporate body may by Act of the Legislature of the Province of British Columbia be authorized and empowered to do and perform, subject to the provisions of this Act.

(2). The Commission shall be and shall be deemed to be an incorporated company created under and by virtue of the laws and having its chief place of business and head office in a British possession, namely, the Province of British Columbia, within the meaning of the Merchant Shipping Act 1894 and of the Canada Shipping Act, and shall have and may exercise in regard to the ownership and management of shipping and of ships and of shares in ships, and of mortgages and securities upon ships, all the powers of such an incorporated company by the said Merchant Shipping Act 1894 and the Canada Shipping Act and every other Act or Statute as well heretofore conferred as hereafter to be created or conferred.

(3). The Commission as a body corporate as aforesaid shall have power to and may own, hold, buy, operate, sell, lease, manage, build, charter, and rebuild and repair ships, and all kinds and descriptions of property, of whatsoever tenure, nature, or kind.

5. The Superintendent shall be appointed by the Lieutenant-Governor in Council and shall ex officio be a Director of the Commission.

6. One Director shall be appointed by the Lieutenant-Governor in Council. The Superintendent and the Director appointed by the Lieutenant-Governor in Council, if holding any other office or place in the Civil Service of British Columbia, shall only receive under this Act such payment for actual services rendered as may be provided for by Order in Council, including allowance for actual necessary expenses.

7. The Deputy Minister of Finance for the time being shall ex officio be a Director of the Commission.

8. The existing or continuing Directors of the Commission shall have and may execute all the jurisdiction and powers of the Commission notwithstanding any vacancy or vacancies in the membership thereof. 
9. (1) The Lieutenant-Governor in Council may from time to time appoint some fit and proper person to be and act as Deputy Superintendent. The Deputy Superintendent shall hold office during pleasure of the Commission.

(2). On the occurrence from any cause of a vacancy in the office of Superintendent and in case of absence from duty of the Superintendent, the Deputy Superintendent for the time being shall have and may exercise all the powers, duties, and functions of the Superintendent, except that he shall not vote at any meeting of the Commission.

10. (1). The Commission may, with the approval of the Lieutenant-Governor in Council, from time to time appoint and employ all such persons as may be required for the transaction of the Commission's affairs and business.

(2). All appointees and employees shall hold office during the pleasure of the Commission, and shall be subject to all regulations and to the orders, direction, and control of the Superintendent.

11. (1). The remuneration and fees of the Director, Superintendent, Deputy Superintendent, office staff, Appraisers, and Inspectors, and all other appointees, employees, or agents employed by the Commission, shall be determined from time to time by the LieutenantGovernor in Council.

(2) No remuneration for services rendered under this Act shall be paid to the Deputy Minister of Finance, except his actual and reasonable expenses when travelling in service of the Commission.

12. (1). The Commission shall have power to make, amend, vary, repeal, replace, and remake, and shall and may from time to time make, regulations not inconsistent with the this Act relating to such matters as-

(a) The meetings and proceedings of the Commission;

(b) The respective duties of the staff and of other persons employed by the Commission;

(c) The fees payable by borrowers under the provisions of this Act;

(d) The conditions that may be imposed in regard to loans;

(e) The forms to be used, and the books, accounts, and records to be kept; and

(f) Generally to make and enforce such other rules and regulations as may be required for fully and effectually carrying out the provisions of this Act.

(2). All such regulations, when confirmed by Order in Council and when published in the British Columbia Gazette, shall have the force of law and the same effect as if they were embodied in this Act, and shall be laid before the Legislative Assembly within 10 days after the date of publication, or if the Assembly is not then in session, within 10 days from the commencement of the next ensuing session.

13. All deeds, instruments, and other documents and all securities to be executed by the Commission pursuant to this Act may be executed by the Superintendent or by one of the Directors by signing his name and affixing the seal of the Commission in the presence of one other member of the Commission or of the Deputy Superintendent, who shall subscribe his name as witness, and when so executed such deeds, instruments, documents, and securities shall be deemed to have been validly and effectually executed and delivered by and on behalf of the Commission.

14. The Commission shall, with the consent of the Lieutenant-Governor in Council, establish 
a head office, and may with the like consent from time to time establish district offices as may be required and move the head office or any district office. Meetings of the Commission shall be held at the head office: Provided that by majority vote of the Directors of the Commission a meeting of the Commission may be held at any place in British Columbia.

15. All transcripts of the instruments, records, registrations, papers, and documents made for the purpose of the establishment of district officers shall prima facie be deemed to be true copies of the several instruments, records, registrations, papers, and documents of which they purport to be transcripts; and such transcripts, or copies thereof, under the seal of the Commission, certified by the Superintendent, shall be admissible in evidence in all Courts in this Province without proof of sealing or signature.

16. The Commission shall have an official seal inscribed with the words "Shipping Credit Commission of British Columbia," and may prescribe a seal for each district office which shall have in addition the name of the district inscribed thereon. Every paper, writing, or instrument impressed with the seal of the Commission, and signed by or on behalf of the Commission, shall thereupon be admissible in evidence in all Courts in this Province without proof of such sealing, or of the signature of the Superintendent or Director, or deputy, or person signing on behalf of the Commission; and every paper, writing, or instrument sealed with the seal of the district office and purporting to be signed on behalf of the Commission shall be admitted in evidence in like manner.

17. (1). The Commission shall meet once at least in every month and at such other items as the Superintendent may convene meetings. The Superintendent shall call a meeting of the Commission on the written request of any Director of the Commission.

(2). The Directors of the Commission shall at their first meeting, by majority vote, elect one of their number to be Chairman of the Commission for such period as may be fixed by resolution, and thereafter from time to time select a successor in the office of Chairman for any period fixed by resolution.

(3). In the absence of the Chairman from any meeting of the Commission, the Directors present shall appoint one of their number to be Chairman for that meeting.

(4). At every meeting the Chairman shall have a casting vote in the event of there being an equality of votes in respect of any resolution in addition to his ordinary vote as a Director of the Commission.

(5). Two Directors of the Commission shall constitute a quorum.

18. The Commission shall at all times cause proper minute books to be kept, in which shall be entered full and accurate minutes of all the proceedings at each meeting of the Commission.

19. A resolution of the Commission shall be binding upon the Superintendent in the conduct of the business and affairs of the Commission.

20. An annual report shall be made by the Commission to the Lieutenant-Governor in Council not later than 30 days after the close of each calendar year, and each annual report shall be laid before the Legislative Assembly not later than the $10^{\text {th }}$ day of February if the Assembly is then in session, and if not, then not later than 10 days after the commencement of each ensuing session. 


\section{Securities and Loans}

21. (1). It shall be lawful for the Commission to lend money by making loans for purposes authorized by this Act to any person or company, subject always to the provisions of this Act.

(2). In addition to all other powers by this Act conferred, the Commission shall be and is hereby authorized and empowered to engage in the business of and to do and to perform all acts necessary and incidental to the business of lending monies at interest on mortgage of any ship and on mortgage of shares in any ship, including full powers of taking, holding, and realizing upon securities comprising all classes of real and personal property; wheresoever or howsoever situate, and of whatsoever kind or nature, according to the several tenures and qualities thereof respectively, as collateral or further security for the repayment of any mortgage upon any ship or ships or shares in a ship, with power to take such collateral security either at the time of the making of any original loan or at any time thereafter.

22. (1). The working capital of the Commission shall be such monies as may be raised from time to time by the issue of securities under this act, and such other monies as may be appropriated from time to time for the Commission's purposes by the Legislative Assembly, and such money as may otherwise become available from time to time under the operation of this Act.

(2). The Commission may from time to time, with the approval of the LieutenantGovernor in Council by Order in Council, make, execute, deliver, and issue securities in such sum, for such period, and at such rate of interest as the Minister may determine.

(3). All securities shall be sold through the Department of Finance by the Minister, who shall determine the limit of price below which the securities shall not be negotiated, sold, or disposed of.

(4). The due payment of all such securities, both as to principal and interest, shall be unconditionally guaranteed by the Crown in right of the Province of British Columbia.

(5). Every guarantee of securities pursuant to subsection (4) of this section shall be signed by the Minister, or such other officer as may be thereto designated by the LieutenantGovernor in Council, and upon being so signed the Province of British Columbia shall become liable for the payment of the principal and interest of the securities guaranteed according to the tenor thereof; and the Lieutenant-Governor in Council is hereby authorized to make arrangements for supplying the monies necessary to fulfill the requirements of the said guarantee, and to advance the amount necessary for that purpose out of the general revenue of the Province; and in the hands of any purchaser, pledgee, or other person acquiring any of such securities the said guarantee so signed shall be conclusive evidence that the terms of this Act with respect thereto have been complied with.

(6). Subject to the proviso in this subsection contained, the first or primary deed of trust (hereinafter called "the original instrument") securing the securities provided to be guaranteed under this Act, and every other deed of trust thereafter made, shall provide for the issue, from time to time, and ranking pari passu with said securities and without preference or priority one over the other, of additional securities of similar kind, tenor, and effect: Provided always that before such additional securities are issued to an amount which will make the aggregate amount of outstanding securities exceed $\$ 2$ million, the guarantee by the Province of the payment of the principal and interest thereon shall first have been authorized by the Legislature, and that such guarantee shall first have been given pursuant to such 
authorization.

(7). Supplementary deeds of trust (hereinafter called "supplementary instruments") in form approved by the Lieutenant-Governor in Council shall be taken to the trustees for the time being of the original instrument, and such additional securities shall be issued under the terms of the original instrument and supplementary instruments, which, together with the mortgaged premises and property covered thereby, shall form the security for all the securities.

(8). The collective amount of such securities shall be always protected and secured by the total amount of mortgages held by the Commission, and by all the property of the Commission, together with funds awaiting investment in the treasury of the Commission.

(9). All sums raised as provided in this section shall, as and when raised, be paid into the Shipping Credit Commission's Account hereinafter referred to.

23. The principal sum and interest for which any securities as provided in this Act have been issued shall be chargeable upon and be paid out of monies arising from the operation of this Act; and so far as funds for the payment of any such principal sum and interest shall not be available for such purpose, any sum of principal or interest shall be chargeable upon and paid out of the Consolidated Revenue Fund of the Province, which last mentioned fund shall in respect of any such payment be reimbursed from the Shipping Credit Commission's Account, mentioned hereinafter, as and when monies available for such purpose may have accrued.

\section{The Commission's Account}

24. All monies raised in pursuance of section 22 hereof and all other monies belonging to or payable to the Commission shall be paid into a bank to be designated by the LieutenantGovernor in Council to the credit of an account to be called the "Shipping Credit Commission's Account."

25. (1). There shall from time to time be charged to and be paid out of the Shipping Credit Commission's Account without further appropriation than by this Act made, -

(a) The cost and expense incurred in raising monies for the Commission by the Minister;

(b) All sums payable in respect of interest on the securities for the monies raised under authority of this Act;

(c) All monies required to be set aside for sinking funds and reserve funds;

(d) All monies required for the payment or redemption of securities issued in respect of the monies raised as aforesaid;

(e) All monies required for the purpose of making loans under this Act.

(2). All cost and expense of management of the Commission's office and of the administration of this Act, including salaries and fees, shall be payable out of the Shipping Credit Commission's Account.

(3). Transfers of money may be made from the Shipping Credit Commission's Sinking Fund Account to the Shipping Credit Commission's Account whenever and wherever necessary to enable payment or redemption of securities to be effected under subsection (d) of this section.

26. All monies withdrawn from the Shipping Credit Commission's Account or the Sinking 
Fund or Reserve Fund shall be withdrawn only by cheque signed by any two Directors of the Commission.

27. Any of the monies in the Shipping Credit Commission's Account may, until required for use in carrying out the purpose of this Act, be temporarily invested from time to time in and upon such securities as may be approved by Order in Council, and all monies received in respect of interest on any such investment shall be paid into the Shipping Credit Commission's Account.

28. All monies in the Shipping Credit Commission's Account or payable to the Shipping Credit Commission's Account by any person whomsoever, also all monies owing under this Act by any mortgagor or borrower, whether the same are accrued due or not, are hereby declared to be the property of the Crown in the right of the Province of British Columbia, represented by and acting through the Commission, and recoverable accordingly as from debtors to the Crown.

\section{Reserve Funds}

29. In connection with the Commission's business, and out of funds belonging to the Commission, there shall be established, and invested in and upon such securities as may be approved by Order in Council, a Reserve Fund, to which shall be carried all the net surplus earnings of the Commission and any other monies by this Act directed until the Reserve Fund shall consist of such sum, not being less than $\$ 100,000$, as the Lieutenant-Governor in Council may from time to time direct.

30. (1). Any losses which may be incurred under the operation of this Act shall be paid out of the Reserve Fund.

(2). If at the end of any calendar year there is found to exist a deficiency in the Reserve Fund for the payment of losses, such deficiency shall be made up and paid out of the Consolidated Revenue Fund of the Province, which last mentioned fund shall be reimbursed whenever sufficient funds have accrued to the Commission's Reserve Fund, and may be available for such reimbursement.

\section{Sinking Fund}

31. There shall in each year be paid out of the Shipping Credit Commission's Account and into an account with the bankers of the Commission for the timing being, and called the "Shipping Credit Commission's Sinking Fund Account," all monies received by the Commission in payment of the principal monies of loans under this Act, together with such further amounts from interest collections and from other earnings (if any) on loans as may be necessary in order to provide for the redemption at maturity of all the respective securities from time to time issued under this Act; subject always to payment in the first place of all interest on all guaranteed securities; sot that the monies from time to time received by the Commission under this Act shall always be applied as follows, that is to say:-

Firstly: In payment of the interest on all guaranteed securities for the time being outstanding;

Secondly: In payment of the amounts necessary to keep the Sinking Fund up to the necessary amount and standard to duly and fully provide for the redemption of all guaranteed securities at maturity; 
Thirdly: In payment of all costs and expenses of the management and administration of the Commission;

Fourthly: In keeping up the Reserve Fund to the amount fixed by Order in Council after making of all necessary reimbursements to the Consolidated Revenue Fund; and

Lastly: Into the Shipping Credit Commission's Account for reinvestment as part of the funds of the Commission.

32. The monies standing to the Credit of the Shipping Credit Commission's Sinking Fund Account shall be invested in and upon such securities as may from time to time be prescribed by Order in Council.

\section{Miscellaneous Accounts}

33. In connection with the Commission's business there shall be kept within the Commission's records separate accounts showing-

(a) The Capital Fund, the securities outstanding;

(b) The loans made;

(c) The interest received;

(d) Other earnings received;

(e) Such other particulars as the Minister may from time to time deem necessary in order to show the details of all transactions and the exact financial position of the Commission

34. (1). The Commission shall cause to be kept in its office a separate register of all loans made by the Commission.

(2). The register of loans as aforesaid shall be kept in such form as may be prescribed.

\section{Division (2) - Loan Regulations}

35. (1) It shall be lawful for the Commission to make loans upon ships built and registered in the Province of British Columbia, and to accept as security for the repayment of such loans mortgages upon such ships and shares in such ships and such further and collateral security as the Commission in its absolute discretion may from time to time see fit, to the end and intent that the Commission in taking security may exercise every power in and by this Act created and conferred upon the Commission and every power conferred upon and vested in a mortgagee by the provisions of the Merchant Shipping Act 1894 and the Canada Shipping Act.

(2) Provided that no loan shall be made behind any prior loan or lien.

36 (1) No loan shall be considered except upon the written application of the borrower.

(2) Such application shall be in the prescribed form and shall set forth distinctly and definitely the purpose for which the loan is required.

(3) Each such application shall be accompanied with the prescribed fees.

(4) An applicant for a loan shall furnish such additional details, references, and information as the Commission may at any time require.

37. No loan shall be made except upon a recorded resolution of a meeting of the Commission at which the question of granting the loan has been fully considered. 
38. No loan shall be granted for an amount exceeding 55 percent of the ascertained value of the ship or shares in a ship offered as security for the loan.

39. The amount of any loan granted under any part of this Act may in the discretion of the Commission be advanced by installments.

40. In any case when the granting of a loan has been approved by the Commission, and the applicant fails within three months after notification to him of such approval to execute any documents that may be required in order to complete the security of the loan to the satisfaction of the Commission, and to file the same with the Commission, together with the title deeds (or certificates, as the case may be) of the property, the Commission may withdraw its approval of the loan. In such event no part of the fees paid in connection with the application shall be refunded.

41. No loan shall be made to any member of the Commission, or to any member of the staff of the Commission, or to any Appraiser, Inspector, or person employed to perform any work on behalf of the Commission.

42. No Director in his office as a member of the Commission shall at any meeting take part in the discussion or vote in the following cases, that is to say:-

(a) Any application for a loan under this Act by any person who is related to that member within the third degree of consanguinity; or

(b) Any application for a loan on behalf of any person who is in partnership with or in the employ of that member; or

(c) Any application for a loan by any person who is a debtor under a mortgage to any association of which that person is a director or member, or under which he holds any office or position.

43. Every mortgage under this Act shall be given to the Commission, its successors and assigns, and shall be made and taken in the prescribed form so as to comply wherever necessary with the provisions of the Merchant Shipping Act 1894 and Canada Shipping Act.

44. The following provisions shall apply to and shall be enforced and carried out in respect to every loan made and to every subsidy paid by the Commission:-

(a) The plan and specification of the ship shall be such as may be approved by the Commission, and the ship shall be so constructed as to obtain a class in Lloyd's; Bureau Veritas; British Corporation; or other recognized classification or specifications satisfactory to the Commission;

(b) Such rate of wages as the Commission may decide to be a fair wage rate shall obtain in respect of all work done in and about the construction of the ship and in and about the manning and operation of the ship;

(c) The Superintendent of the Commission or such person as may from time to time be approved of by the Commission shall be the managing owner of the ship until the loan is fully repaid;

(d) The ship shall not be sold or transferred, except with the consent of the Commission, for 5 years from the date of the making of the loan; and shall utilize its cargo-carrying capacity to the full extent thereof on each voyage outwards from British Columbia, and shall be operated continuously to the satisfaction of the Commission; 
(e) Every outward charter of the ship shall be subject to the approval of the Commission during the currency of the loan; and the rates of freight on British Columbia shipments shall never exceed the actual rates paid on similar commodities at even dates in the State of Washington, State of Oregon, and the State of California, and the Commission shall have power to and may from time to time ascertain and certify such rates;

(f) All insurance on the ship, including marine risks, fire risk, war risks, employers' liabilities risks, casualty risks, and risks during construction, shall be made loss payable to the Commission as its interest may appear and exist, and shall be carried in any amount which the Commission may deem necessary or expedient;

(g) The contract between the Commission and the borrower shall contain, and notwithstanding any omission in the form of contract be deemed to always contain, a provision whereby 1 percent of the gross earnings of the ship during the currency of the loan shall be paid into the Reserve Fund of the Commission as a payment from the shipping industry benefited by this Act towards the governmental risk, cost, and expense of passing this Act and carrying its provisions into effect.

45. All records and documents under this Act shall be in the prescribed form.

46. Each loan made by the Commission under this Act shall bear interest at the rate of 6 percent per annum, payable half yearly, and the principal sum shall be made payable in the manner following, that is to say, in 5 equal annual installments: Provided that if 50 percent of the net earnings of the ship for any year shall exceed the annual installment of repayment of principal with interest as hereinbefore required, then the borrower shall repay a further sum so that the amount paid each year in reduction of the loan shall never be less than 50 percent of the net earnings of the ships, and never less than 20 percent of the original amount of the loan without reference to earnings.

47. If at any time any sum of money whether principal or interest, due in respect of any loan made by the Commission under the provisions of this Act on the security of a mortgage of land held in fee simple be unpaid; of if in the opinion of the Commission any such loan, or portion of such loan, has not been applied for the purpose for which it was made, or has not been carefully and economically expended; or if the loan be not applied within such time as the Commission may consider reasonable for the purpose for which it has been made, or if any default is made in the observance of any covenant in any mortgage, the Commission may in any and all such cases as aforesaid refuse to pay any unpaid portion of the loan, and one month after demand by registered mail has been made for repayment of the loan, or such portion thereof which may have been advanced, and without recourse to a Court of law, enter upon, seize, and take possession of the whole or any part of the security for the loan; and the Commission may dispose thereof as it sees fit at public auction, public tender, or private sale, upon such terms and conditions as it deems under all the circumstances to be just, and the Commission may transfer such land or other security to any purchases it sees fit, and give a good and valid title thereto, notwithstanding any encumbrance thereon in favor of any other person.

48. The Commission shall apply the proceeds derived from such sale in payment, in the first instance, of all monies due to the Commission in respect of such loan, and in redemption of 
any amount charged thereon in favor of the Commission, or so much thereof as remains unpaid, or in making any pro rate division to any other encumbrancer if there be any agreement with the Commission to that effect, and in payment of all expenses incurred by the Commission in relation to such sale, and shall pay the balance (if any) to the persons entitled to receive the same.

49. (1). If the Commission is unable to resell any property which it has taken over on account of unsatisfied loan at a price sufficient to repay the monies due in connection with such loan, then it shall be lawful for the Commission, with the consent of the Lieutenant-Governor in Council, to reduce the amount of the price so as to effect a sale.

(2) Any loss arising from a resale as provided in the last preceding section, or from any sale in pursuance of the mortgage, shall be debited to the Reserve Fund.

50. In the event of default being made in payment of any monies due under any mortgage, or for any of the causes under which the Commission may exercise power of sale as set out in section 47 of this Act, the Commission may, in addition to the exercise of all other rights and remedies, and without notice, appoint a receiver of the mortgaged premises, with full power to enter into and upon and take possession of and to manage and realize upon the mortgaged premises, and to exercise all such further or other powers as may from time to time be prescribed.

51. It shall not be lawful for any member of the Commission, or for any official, appointee, or employee of the Commission, to buy, directly or indirectly, any property sold by the Commission under this Act.

\section{Fees}

52. (1) Fees, costs, and charges shall be payable by any applicant for a loan under this Act according to the scale for the time being prescribed.

(2) All fees, costs, and charges payable to the Commission by applicants for loans under the provisions of this Act shall be paid in advance.

\section{Aid to Shipping}

53. In aid of the shipbuilding industry in the Province of British Columbia there shall be paid to the owner of each ship (as defined in this Act), up to a number of ships not exceeding 25 ships or such further number as may hereafter be provided by Act of the Legislature, constructed and launched in this Province after the passing of this Act a subsidy in 10 annual installments, each of which installments shall be so computed as to bring the net earnings of the ship in respect whereof it is paid up to 15 percent on the actual cost thereof as certified by the Commission for the year in respect whereof payment is made but so that the subsidy paid in any one year shall never exceed an amount equal to $\$ 5$ per ton in respect of each ton of dead weight cargo capacity of the ship as certified by the Commission, with provision for a safe free board, and the first of which installments shall be payable and paid in respect of the first year after the declaration of peace in respect of the present War, and thereafter annually until the full subsidy has been paid, subject only to bona fide user of the ship in British Columbia trade for outward borne cargoes, returning to some British Columbia port for reloading, with liberty to carry return cargo to any port along the general practicable line of such return to British Columbia; and all monies necessary for the due and complete payment 
of all subsidy aforesaid may and shall from time to time be paid out of the Consolidated Revenue Fund to the Commission and the Commission may make payment to the respective owners subject to the provisions following:-

(a) The subsidy shall only be payable and paid to the owner who actually paid for the construction of the ship, or to his assigns who actually operate the ship, and not to any middleman or promoter;

(b) A subsidy shall not be liable or subject to assignment, attachment, garnishment, or process of execution whatsoever;

(c) In the event of there being conflicting claims to payment of a subsidy, the decision of the Commission shall be absolutely final and binding and without appeal.

\section{Establishment of Shipbuilding Plants}

54. The Commission may from time to time, with the sanction and approval of the Lieutenant-Governor in Council by Order in Council, contract with any person or company for establishment of one or more ship building, repairing, and docking plants in the Province of British Columbia, or any branch of such a plant, or for the extension, acquisition, or improvement of any existing plant, upon such terms and conditions as may be thought fit, and particularly upon the condition that in respect of such shipbuilding plant securities may be issued by such person or company up to an amount not exceeding 55 percent of the actual cost of such shipbuilding plant as certified by the Commission; and the due payment of all such securities, both as to principal and interest not exceeding 6 percent per annum, shall in the first instance be undertaken and contracted to be made by the person or corporation establishing, extending, acquiring, or improving the shipbuilding plant, and the due payment of all such securities, both as to principal and interest, shall be unconditionally guaranteed by the Crown in right of the Province of British Columbia, and the provisions of section 22 of this Act shall apply to such securities, save insofar as otherwise provided in this section, and so that the securities guaranteed shall always constitute a first charge on the shipbuilding plant and property used therefor, and shall not be subject to any prior lien or charge whatsoever, except Provincial or municipal rates, taxes, and assessments:

(a) The Commission shall have power to decide all questions and matters arising under this section and to pay over the loan monies to the borrowers, subject always to authority by Order in Council first had and obtained.

\section{Miscellaneous Provisions}

55. For the purpose of putting the provisions of this Act into effect until such time as the necessary funds for such purpose shall be available under the operation of said Act, there may be advanced by the Minister, under authority of any Order of the Lieutenant-Governor in Council, out of the Consolidated Revenue Fund of the Province, a sum not exceeding $\$ 50,000$, which sum may be expended under the direction of the Minister, and the last mentioned fund shall be reimbursed from monies accruing under the operation of this Act when available for such reimbursement.

56. All declarations authorized to be made under the provisions of this Act shall be subscribed by the person making the same, and shall be made before Notary Public, Justice of 
the Peace, or any other person duly authorized to take declarations, or before the Superintendent, who is hereby fully authorized and empowered to receive the same.

57. The Lieutenant-Governor in Council may from time to time make such rules, orders, and regulations as may be required for the purpose of effectually carrying out the provisions of this Act; and every such rule, order, or regulation shall have the same force and effect as if it had been enacted herein.

58. The Commission may, by writing under its common seal, empower any person, either generally or in respect of any specified matters, to act as its general agent or special agent, and as attorney in fact, and as its attorney and to execute deeds on its behalf in any place situate within or without the limits of the Province; and every deed signed by such attorney on behalf of the Commission and under his seal shall bind the Commission and have the same effect as if it were under the common seal of the Commission.

59. In the event of any subsidy to shipping being paid by the Dominion of Canada to any ship or in respect of any ship claiming subsidy under this Act, the amount of the subsidy paid by the Dominion of Canada shall be deducted from the subsidy payable under this Act, and only the deficit (if any) after such deduction shall be paid under this Act, and so from time to time.

60. This Act shall come into force on such day as may be fixed by the Lieutenant-Governor in Council by Order in Council.

[The British Columbia Shipping Act was repealed 16 December 1922, Statutes of British Columbia 1922, chap. 71.]

\section{Appendix B: the Dry Docks Subsidies Act.}

"An Act to encourage the Construction of Dry Docks," Revised Statutes of Canada 1927, chap. 191 [This version incorporates the original 1910 statute as well as amendments passed through legislation in 1917, 1919, and 1923]

\section{Short Title}

1. This Act may be cited as the Dry Docks Subsidies Act.

\section{Interpretation}

2. In this Act, unless the context otherwise requires, "Minister" means the Minister of Public Works, and "dry dock" and "dock" include floating dry docks.

3. (1) The Governor in Council may as an aid to the construction of any dry dock, authorize the payment out of any un-appropriated money forming part of the Consolidated Revenue Fund of Canada of a subsidy, in accordance with the provisions of this Act, to any incorporated company, approved by the Governor in Council as having the ability to perform the work, which shall enter into an agreement with His Majesty to construct a dry dock under the provisions of this Act, with all necessary equipment, machinery, and plant, for the reception and repairing of vessels. 
(2) No such aid shall be granted unless the Governor in Council is satisfied, upon a report of the Minister, based upon a report of the chief engineer of the Department of Public Works, and such other evidence as he deems necessary, that such dry dock is needed in the public interest, and is, as proposed, of sufficient capacity to meet the public requirements where such dry dock is to be located.

4. (1) For the purpose of constructing a dry dock under the provisions of this Act, the company entering into the agreement contemplated by the last preceding section may utilize or acquire for the purpose of utilizing, the works and property of any existing dry dock company whose dock has been constructed under the provisions of chapter 17 of the statutes of 1882 , chapter 9 of the statutes of 1899, chapter 116 of the Revised Statutes 1906, or chapter 24 of the statutes of 1908, and the value of such works and property at the time when the agreement is entered into, so far as such works and property may be useful in the construction of a dry dock of greater dimensions or capacity under this Act, shall be deemed to be for the purposes of subsidy calculation a part of the cost of the dry dock constructed under this Act.

(2) The aggregate amount of all subsidies paid by the Governor in Council, in respect of the dock so utilized under any of the said chapters $17,9,116$, or 24 , before the agreement to construct under the provisions of this Act is entered into, shall be deducted from the subsidy payable under this Act, and such deduction shall be made in equal annual portions during the period in respect of which subsidy is payable under this Act; and the remaining payments, if any, of subsidy called for by the agreement entered into under any of the said chapters shall not be made.

(3) For the purposes of this section the value of the works and property of any existing dry dock company shall be estimated by the Minister, based upon a report of the chief engineer of the Department of Public Works; and the Governor in Council, having regard to such estimate, shall determine the value of such works and property, and such amount shall be so determined before the said agreement is entered into.

5. Any company which seeks to enter into an agreement with His Majesty to construct a dry dock under this Act shall, as part of its application therefor, present detailed working plans and specification of the proposed works, accompanied by estimates of the cost thereof, including estimates of the cost of all necessary equipment, machinery, plant and site, provided the company is obliged to pay for the site in cash and does not obtain or has not obtained a site way of bonus or gift, and such estimates of cost shall be in such detail as shall enable the chief engineer of the Department of Public Works to verify the same for the purposes of the report required to be made by him under section eight of this Act.

6. If the company, after it has entered into an agreement with His Majesty to construct a dry dock under this Act, is unable to agree with the owner of any lands or immovable property, or interest therein, which land or immovable property or interest is deemed by the company necessary for a site for such dry dock, as to the purchase, acquisition, or transfer thereof, or the price to be paid therefor, the company may, upon the approval of the Governor in Council, acquire such lands or immovable property or interest without the consent of the owner, and shall in such cases, for all purposes of the taking, acquiring, ascertaining the value of and making compensation for the said lands or immovable property or interest have all the powers of a railway company under the Railway Act relative to the taking and using of lands, and the compensation and damages therefor, and the Railway Act shall, mutatis mutandis and insofar as applicable, apply to the taking and acquiring of, and the ascertaining and payment of the 
compensation and damages for, such lands, immovable property or interest by the company.

7. Dry docks constructed under the provisions of this Act shall, for the purposes of this Act, be divided into three classes, as follows:-

(1) Dry docks of the first class for naval and general purposes costing, for the purposes of the subsidy calculation, not more than $\$ 5.5$ million in the case of dry docks specified in subparagraph (a) and not more than $\$ 4$ million in the case of dry docks specified in subparagraph (b) hereunder, being

(a) dry docks, other than floating dry docks, of dimensions when completed of not less than the principal dimensions next hereinafter mentioned, that is to say, clear length on bottom from caisson groove or hollow-quoin to head, 1,100 feet, clear width of entrance, 125 feet, depth of water over sill at high water ordinary spring tides, 38 feet; and

(b) floating dry docks of a lifting capacity of at least 25,000 tons, in which vessels can with ease and safety be received and repaired:

Provided, however, that any such dry dock shall not, for the purposes of this Act, be deemed to be a dry dock of the first class unless there can be received and repaired therein with ease and safety the largest ships or vessels of the British Navy existing at the time at which the contract is entered into;

(2) Dry docks of the second class, costing for the purposes of subsidy calculation not more than $\$ 2.5$ million; being

(a) dry docks, other than floating dry docks, of dimensions when completed not less than the principal dimensions next hereinafter mentioned, that is to say, clear length on bottom from caisson groove or hollow-quoin to head, 650 feet, clear width of entrance, 85 feet, depth of water over the sill at high water ordinary spring tides, 30 feet if constructed on tidal waters and 25 feet over the sill at ordinary low water if constructed on non-tidal waters; and

(b) floating dry docks of a lifting capacity of at least 15,000 tons, and in which vessels can with ease and safety be received and repaired;

(3) Dry docks of the third class, costing for the purposes of subsidy calculation not more than $\$ 1.5$ million; being

(a) dry docks, other than floating dry docks of dimensions when completed not less than the principal dimensions next hereinafter mentioned, that is to say, clear length on bottom from caisson groove or hollow-quoin to head, 400 feet, clear width of entrance, 65 feet, depth of water over the sill at high water ordinary spring tides, 22 feet if constructed on tidal waters and 18 feet over the sill at ordinary low water if constructed on non-tidal waters; and

(b) floating dry docks of a lifting capacity of at least 3,500 tons, and in which vessels can with ease and safety be received and repaired.

8. The cost on which the subsidy shall be calculated shall be fixed and determined by the Governor in Council upon the recommendation of the Minister, based upon a report of the chief engineer of the Department of Public Works, accompanied by plans and specifications of the proposed works, and such cost shall include the cost of all necessary equipment, machinery, and plant, and any sum bona fide expended or to be expended by the company in the purchase of a site for the dry dock, but shall not include the value of any site received or 
to be received by the company by way of bonus or gift; and the amount of the subsidy shall be so fixed and determined before the agreement for payment of the subsidy is entered into.

9. (1) The subsidy payable in respect of dry docks which have been constructed under this Act of the first class shall be a sum not exceeding 4.5 percent per annum of the cost of the work as fixed and determined under the last preceding section, half yearly during a period not exceeding 35 years from the time the Governor in Council has determined under this Act that the work has been completed.

(2) No bonds, debentures, or other securities, shall be issued with respect to and as a charge upon any dock until it has been established to the satisfaction of the Minister that not less than $\$ 1$ million have been spent on the work and the material upon or for such dock, and that there are no outstanding and unsettled liens, encumbrances, or claims upon or in respect of such dock, but thereafter the Minister may permit the issue of bonds, debentures, or other securities, and any subsidy mentioned by this section may, with the approval of the Minister, be assigned to a trustee for the holder of such bonds, debentures, or other securities, and the subsidy shall, in that event, be payable directly to such trustee, but, until the dock has been completed to the satisfaction of the Minister, the total amount of the bonds, debentures, or other securities issued shall not at any time exceed 75 percent of the amount actually expended for the work and the materials upon or for the dock, and in no case shall any bonds, debentures, or other securities, be issued without the consent in writing of the Minister.

(3) Half yearly payments on account of the subsidy at the rate of 4.5 percent per annum on 75 percent of the cost of all work done and materials provided at the time such payment may be made during the construction of the said dock, and for such period as may be determined by the Governor in Council, not exceeding 35 years from, and including, the first payment thereof, the amount of such cost to be determined by the chief engineer of the Department of Public Works, but no such payment on account shall be made until the work done and materials provided shall have cost the sum of at least $\$ 1$ million.

(4) No such payments on account shall be made unless the said chief engineer reports that the work of construction of the dry dock with respect to which the payment is to be made has been done to his satisfaction, and no subsidy shall be paid except payments on account as aforesaid unless the Governor in Council, in the manner prescribed in this Act, has determined that the work required by the agreement is completed.

(5) The total subsidy, including such payments on account during construction shall not, however, in any case, exceed the amount of subsidy hereinbefore authorized.

(6) When the amount actually expended for the work and the materials upon or for the dock shall have equaled at least 75 percent of the cost thereof as fixed and determined under the provisions of this Act and the chief engineer of the Department of Public Works shall have certified thereto and shall have further certified that such work has been done to his satisfaction, half yearly payments on account of the subsidy at the rate of 4.5 of the cost of all work done and materials provided at the time of such payment but in all other respects the provisions of this Act shall apply to the issue of any bonds, debentures, or other securities and to any payments on account of the subsidy during construction of the said dock.

10. (1) The subsidy payable in respect of dry docks of the second class, which have been constructed under this Act, shall be a sum not exceeding 4.5 percent of the cost of the work as fixed and determined under section 8 , half yearly during a period not exceeding 35 years from 
the time the Governor in Council has determined under this Act that the work has been completed.

(2) No bonds, debentures, or other securities shall be issued with respect to and as a charge upon any dock until it has been established to the satisfaction of the Minister that not less than \$1.5 million have been spent on the work and the material upon or for such dock, and that there are no outstanding and unsettled liens, encumbrances, or claims upon or in respect of such dock, but thereafter the Minister may permit the issue of bonds, debentures, or other securities, and any subsidy mentioned by this section may, with the approval of the Minister, be assigned to a trustee for the holder of such bonds, debentures, or other securities, and the subsidy shall, in that event, be payable directly to such trustee, but, until the dock has been completed to the satisfaction of the Minister, the total amount of the bonds, debentures, or other securities issued shall not at any time exceed 75 percent of the amount actually expended for the work and the materials upon or for the dock, and in no case shall any bonds, debentures, or other securities be issued without the consent in writing of the Minister.

(3) Half yearly payments on account of the subsidy at the rate of 4.5 percent per annum on 75 percent of the cost of all work done and materials provided at the time of such payment may be made during the construction of the said dock, and for such period as may be determined by the Governor in Council, not exceeding 35 years from, and including, the first payment thereof, the amount of such cost to be determined by the chief engineer of the Department of Public Works, but no such payment on account shall be made until the work done and materials provided shall have cost the sum of at least $\$ 1.5$ million.

(4) No such payments on account shall be made unless the said chief engineer reports that the work of construction of the dry dock with respect to which the payment is to be made has been done to his satisfaction, and no subsidy shall be paid except payments on account as aforesaid unless the Governor in Council, in the manner prescribed in this Act, has determined that the work required by the agreement is completed.

(5) The total subsidy including such payments on account during construction shall not, however, in any case, exceed the amount of subsidy hereinbefore authorized.

(6) When the amount actually expended for the work and the materials upon or for the dock shall have equaled at least 75 percent of the cost thereof as fixed and determined under the provisions of section 8 of this Act, and the chief engineer of the Department of Public Works shall have certified thereto and shall have further certified that such work has been done to his satisfaction, half yearly payments on account of the subsidy at the rate of 4.5 percent per annum may be made on 90 percent of the cost of all work done and materials provided at the time of such payment but in all other respects the provisions of this Act shall apply to the issue of any bonds, debentures, or other securities and to any payments on account of the subsidy during construction of the said dock.

11. The subsidy payable in respect of dry docks of the third class which have been constructed under this Act, shall be a sum not exceeding 3 percent of the cost of the work, as fixed and determined under section 8 , each year during a period not exceeding 20 years from the time the Governor in Council has determined, under this Act, that the work has been completed.

12. Any agreement under this Act shall be for the construction of a dry dock in accordance with the plans and specifications referred to in section 8 of this Act. 
13. The work of constructing any dry dock for which a subsidy is authorized under the provisions of this Act shall be done under the supervision of the Department of Public Works, and shall be completed within the time limited by, and according to the provisions of, the agreement in that behalf, unless the time for construction is extended by the Governor in Council; and the subsidy shall be payable, during the period agreed to by the Governor in Council under this Act, from the time the Governor in Council, upon a report from the Minister, determines that the work required by the agreement has been completed, and that the reception and repairing of vessels contemplated by this Act may forthwith be proceeded with at the dock.

14. Such agreement shall include a provision that the dock shall, after completion, be kept in repair and working order by the company; and keeping in repair and working order within the meaning of this Act shall include, in the case of a floating dry dock, painting and the employment of such other means to lessen and hinder corrosion of the submerged parts thereof as may be practicable.

15. Whenever it appears to the Governor in Council that any dock constructed under the provisions of this Act is not in a condition of repair and working order, the Governor in Council may authorize and empower the Minister to cause possession to be taken of the dock on behalf of His Majesty and to expend out of any un-appropriated money forming part of the Consolidated Revenue Fund of Canada sufficient to put the dock in a state of efficiency and repair.

16. The Minister shall operate the said dry dock after such repairs are completed and while it is in the possession of His Majesty, and shall charge and collect the tolls or rates approved under the provisions of this Act in respect of the letting or hiring, operation or use of the said dock or of space therein or of any works connected therewith; and he shall, after payment therein of operating expenses and maintenance, apply the balance first in repayment of the advances made under the last preceding section, and secondly in payment of accrued interest on bonds or other fixed obligations or securities of the company.

17. The Governor in Council may at any time direct the delivery of possession of the said dock to the company.

18. (1) No tolls or rates shall be charged or taken by the company in respect of the letting or hiring, operation or use of the said dock, or of space therein, or of any works connected therewith, until the company has submitted a tariff of such tolls or rates and the said tariff has been approved by the Governor in Council; and no by-laws, rules, regulations, or conditions respecting such letting, hiring, operation or use, shall have any force or effect until so submitted and approved.

(2) The Governor in Council may at any time disallow the whole or any part of such tariff or of such by-laws, rules, regulations, or conditions, and may require the company, within a specified time, to submit such tariff, or substitute other tariff, tolls, by-laws, rules, regulations, or conditions in lieu thereof, and, in default, may fix such tariff or prescribe other.

19. (1) Before entering into an agreement for construction of a floating dry dock under the provisions of this Act, the Governor in Council shall ascertain from expert engineering opinion what the probable time will be during which such floating dry dock, with reasonable maintenance, will be serviceable for the reception and repairing of vessels as contemplated by this Act; and if the Governor in Council is not satisfied that, with reasonable maintenance, 
such dock will be serviceable as aforesaid for a period at least twice as long as that during which the subsidy under this Act if payable, then, in such case, provision shall be made in such agreement that the company shall set aside annually such sum, to be therein mentioned, as the Governor in Council may deem sufficient to provide a fund wherewith to renew the whole of the floating part of such dock at the expiry of the time at which that part of the dock shall have ceased to be serviceable.

(2) Such fund shall be kept and invested in such manner as the Governor in Council may direct.

20. Upon the application of the Governor in Council or any minister, member of the King's Privy Council for Canada, ships or vessels in the British Naval Service, in the Naval Service of Canada, and other ships or vessels the property of or employed by His Majesty, shall at all times be entitled to the use of such docks in priority to all other vessels.

21. The company, before receiving the first payment of subsidy under the authority of this Act, and annually thereafter, on or before the first day of January, shall file in the office of the Minister a statement, verified to the satisfaction of the Minister, setting forth the financial state of the company, including a statement in detail of the receipts from every source, and the expenditures for the year. 